\title{
Stem Cell Therapies in Regenerative Medicine and Diabetes Mellitus: Advances, Constraints and Future Prospects
}

\author{
Experimental Obesity and Diabetes Research Lab, Division of \\ Physiology, Zoology Department, Faculty of Science, Beni-Suef \\ University, Beni-Suef, Egypt \\ Address for Correspondence \\ Ahmed OM, Experimental Obesity and Diabetes Research Lab, Division \\ of Physiology, Zoology Department, Faculty of Science, Beni-Suef \\ University, Beni-Suef, Egypt; E-mail: osama.ahmed@science.bsu.edu.eg \\ Submission: $17 \mathrm{Mar}, 2016$ \\ Accepted: 03 June, 2016 \\ Published: 08 June, 2016 \\ Copyright: $\odot 2016$ Ahmed Om, et al. This is an open access article \\ distributed under the Creative Commons Attribution License, which \\ permits unrestricted use, distribution, and reproduction in any medium, \\ provided the original work is properlycited.
}

Ahmed $\mathrm{OM}^{\star}$ and Sayed HM

Keywords: Stem cells; Regenerative medicine; Diabetes mellitus: Stem cell therapy

\begin{abstract}
Stem cell therapy is one of the most promising treatments for the near future. This kind of therapy can ameliorate or even reverse some diseases and have potential applications in regenerative and replacement medicines and diabetes mellitus. The different types of stem cells such as embryonic stem cells, induced pluripotent stem cells and adult stem cells have been proved to be operational in treating diabetes mellitus with clear limitations. The prevalence of diabetes mellitus type 1 and type 2 continues to rise and its complications are serious and may lead to death. The current treatment methods, other than stem cell therapy, do not treat the main causes of the disease and have many limitations. Although insulin injection is the standard therapy for type 1 diabetes mellitus, its exogenous injection cannot mimic insulin secretion from normal $\beta$-cells when blood glucose changes all the time. Thus, how to generate new $\beta$-cells is an important approach for the treatment of type 1 diabetes mellitus. Isolated islets are fragile and susceptible to pro-apoptotic factors and poorly proliferative. In contrast, mesenchymal stem cells (MSCs) are highly proliferative, anti-apoptotic and pluripotent to differentiate toward various cell types. The electrofusion between islets' cells and MSCs produced fusion islets' cells that are more resistant to apoptosis and are able to maintain insulin secretion for long periods. The stem cell therapy is also used for treatment of type 2 diabetes mellitus as well because the disease later progresses to $\beta$-cell dysfunction. Stem cell therapies were clinically applied for improvement of insulin sensitivity and metabolic control in long standing type 2 diabetes mellitus. In addition to the applications of stem cells in the cell therapy of diabetes mellitus, recent trends of studies tend to use the direct reprogrammed adult somatic cells especially endoderm-derived adult cells transdifferentiated into insulin secretory pancreatic $\beta$-cells. However, the use of stem cells especially human embryonic stem cells in research and therapy is subjected to limitations and constraints in many countries due to ethical and religious concerns. In this article, the types of stem cells and their resources and to what extent stem cell research can lead to progresses in regenerative medicine and diabetes mellitus therapies are reviewed. It also sheds light on ethica concerns and future hopes of stem cell use in research and therapy.
\end{abstract}

\section{Introduction}

In the mid $1800^{\circ} \mathrm{s}$, stem cell research history began with the discovery of some cells that could produce other cells [1]. The first stem cells, that are real, were discovered in the early of nineteenth century when some cells were found to bring in to blood cells [1]. Since then, the use of stem cell in research and clinical application began to be developed.

The history of stem cell research involves both animal and human stem cells. In 1970, Friedenstein and his colleagues [1] first isolated adherent stromal cells from whole basement membrane in vitro culture; these cells were fibroblast-like, clonogenic cells with multilineage potential to differentiate into various mesenchymal tissues and hematopoietic-supporting stroma. Owen and Caplan further refined isolation methods and identified mesenchymal stem cell markers [2,3]. In 1998, Thomson et al. isolated cells from the inner cell mass of early embryos and developed the first human embryonic stem cell lines [4]. In the same year, Gearhart derived germ cells from fetal gonad tissue [5].

Following the discovery of the methods for isolation and culture of stem cells as well as their identification by flow cytometry and other techniques, the research and clinical applications in stem cell therapy in regenerative medicine and diabetes mellitus are greatly progressed [6-8].

Diabetes mellitus, a metabolic disease characterized by uncontrolled high blood glucose (BG) levels. It may be considered as global epidemics with continuous increase in its prevalence and incidence worldwide $[9,10]$. A current rating of 371 million cases is found in 2012 and it is expected to reach 552 million by 2030 [11]. Also, it is estimated that $5 \%$ of all deaths in the world are caused by diabetes and the number is increasing rapidly. The main forms of this chronic disorder are type 1 diabetes mellitus (T1DM) and type 2 diabetes mellitus (T2DM). T2DM is far more prevalent (90-95\%) than T1DM, and it arises due to either insufficient insulin synthesis or the body"s inability to respond secreted insulin and leading to glucose build-up in the blood [12]. It emerges at mid age [10,13]. T1DM is much less common (5-10\%) than T2DM and commonly affecting the pediatric/adolescent/young age, because immune complex mediated attack on insulin producing $\beta$-cells of the pancreas [14].

The impairment control of glucose leads to both microvascular and macrovascular complications that frequently result in the other clinical conditions associated with diabetes. The treatments of diabetes by the chemical methods do not treat the causes of the disease and have side effects. Thus, there is an obvious search for the suitable alternative treatment methods. Restoring $\beta$-cell function is a goal for improved therapy of both diseases. This could be achieved by two techniques the first is cell-replacement therapy, and the other way is triggering intrinsic regenerative mechanisms of the pancreas. 
For T1DM, the only available curative therapy is the replacement of the lost $\beta$-cell mass by islet transplantation from cadaveric donors [15]. In vitro, the generation of $\beta$-cells from an unlimited source of self-renewing stem cells, such as embryonic stem cells, might be an alternative approach, due to the shortage of transplantable material $[16,17]$. Studies analyzing the therapeutic effects of stem cells in humans with type 1 diabetes began in 2003 in the Hospital das Clínicas of the Faculty of Medicine of Ribeirão Preto - SP USP, Brazil, and since then other centers in different countries started to randomize patients in their clinical trials [18]. In the regard, Couri et al. found that after 29.8 months following autologous nonmyeloablative hematopoietic stem cell transplantation in patients with newly diagnosed type $1 \mathrm{DM}, \mathrm{C}$-peptide levels increased significantly and the majority of patients achieved a good glycemic control and insulin independence [18]. Zhao et al. reported reversal of type 1 diabetes via islet beta cell regeneration and/or preservation of beta cell mass following immune modulation by cord blood-derived multipotent stem cells [19]. As reported by Regeneration Center of Thailand cures for T1D or gestational diabetes are very low probability [20]. There is a genetic component of the disease that will require gene therapy to reprogram the cells from reverting back to their compromised states however these solutions are just in the clinical trials stage and have not been approved for clinical applications.

For T2DM, the phase 1/phase 2 study of Zhao and his colleagues [21] demonstrated that stem cell educator therapy can regulate the immune dysfunctions and restore the immune balance through the modulation of monocytes/macrophages and other immune cells, both in peripheral blood and in tissues, leading to a long-lasting reversal of insulin resistance, a significant improvement in insulin sensitivity and metabolic control in long-standing T2D subjects. In 2015, Regeneration Center of Thailand announced that the center can help to treat DM with enriched and expanded mesenchymal cells treatment for diabetes safely and without any artificial medicines or need for regular insulin dependency [20]. The diabetic patients are treated by injecting enriched MSC stem cells in to the pancreatic area via intravenous routes or directly (severe cases).

This review sheds light on types of stem cells that are broadly classified into two main categories: embryonic stem cells (ESC) and adult stem cells (ASC) and the progress of stem cell research in the regenerative medicine in the field of treatment of diabetes mellitus.

\section{Types of Stem Cells}

Stem cells can be classified into four broad types based on their origin, viz. stem cells from embryos; amniotic stem cells; stem cells from the umbilical cord; and stem cells from adult. Amniotic, fetal and adult stem cells are evolved from embryonic stem cells and the few stem cells observed in adult organs are the remnants of original embryonic stem cells that gave up in the race to differentiate into developing organs or remained in cell niches in the organs which are called upon for repair during tissue injury [22]

\section{Embryonic stem cells}

Embryonic stem cells (ESCs) are derived from embryos at a developmental stage before the implantation time in the uterus from the inner cell mass of a 5-6 day-old blastocyst $[22,23]$. They are pluripotent cells [24,25]. In embryogenesis, the inner cell mass (ICM) develops into two layers of different cells, these layers are epiblast and hypoblast. The hypoblast forms yolk sac, while the epiblast differentiates into the three germ layers of the embryo; ectoderm, mesoderm and endoderm having potential for forming any body tissue [26]

Human embryonic stem cells are undifferentiated (primitive) cells that can differentiate into all cell types found in adult human body or self-renew. Approximately, the first differentiation event in humans occurs at five days of development. The outer layer of cells separate from ICM and committed to becoming part of the placenta (trophectoderm). The ICM cells have the potential to give any cell type of the body, but after implantation, they are depleted quickly because they differentiate into other cell types with developmental potential, which is more limited [27-30].

Embryonic stem cells have been shown to differentiate in vitro into cells from all three embryonic germ layers (Figure 1). Neurons and skin formed from ectodermal differentiation [31-34] while blood, cartilage, endothelial cells, cardiac cells, and muscle formed from mesodermal differentiation [35-37] and pancreatic cells from endodermal differentiation [38]. So, ESCs might be used for the treatment of several diseases, as diabetes [39], injuries of spinal cord [40] and heart transplantation [41] and liver [42]. Recently, Guenou et al. and Pelligrini and Luca reviewed that human embryonic stem cells (hESCs) can differentiate into mature keratinocytes able on immunodeficient mice to give a pluristratified epithelium $[30,43]$. Jukes et al. reported that mouse and human embryonic stem cells (ESCs) can successfully differentiate into cartilage and bone eliciting their potential in cartilage and engineering of bone tissue [44].

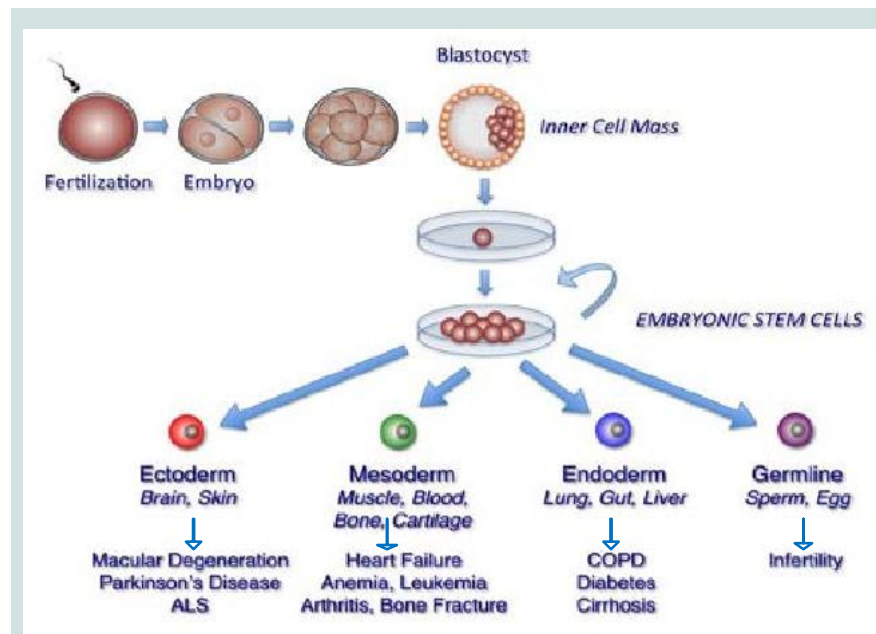

Figure 1: Embryonic stem cell forms the cells of all there germ lavers [45].

Sources of human ES cells: There are four sources of ES cells, which can be derived from embryos in culture during their early stages [46,47]:

1) In vitro fertilization (IVF) for treatments of the infertility; embryos created and were not implanted because they were no longer used.

2) Embryos created by IVF to be used for research purposes. 
3) Already existing embryonic stem cell lines.

4) Embryos created by means of somatic cell nuclear transfer (SCNT) or from cloning techniques. The technique involves replacing the DNA of an unfertilized egg cell with the DNA from a patient's somatic cell, often a skin cell, and then allows the egg to divide to form a blastocyst. The use of somatic cell nuclear transfer into an oocyte has been considered as an asexual or unnatural method of creating blastocyst to harvest embryonic stem cell-like cells for research and therapeutic purposes (Figure 2). If cells or tissues are generated from these ES cells to be transplanted into a person, this tissue type may avoid many of the problems that happened as tissue rejection.

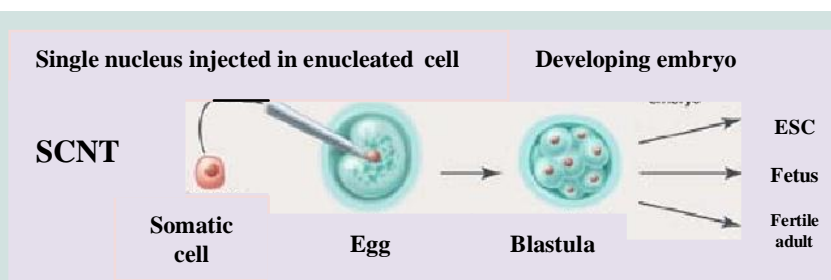

Figure 2: Somatic cell nuclear transfer (SCNT) [48] with permission from Rights Link.

Embryonic stem cells' properties: Embryonic stem cells have eleven properties as indicated by National Institutes of Health, Nichols and Smith, Kawaharada et al. as follows [49-51]:

- They express the transcription factor octamer-binding transcription factor 4 (Oct-4), which then inhibits or activates a host of target genes and maintains ES cells in a proliferative, non- differentiating state.

- They are induced to continue to proliferate or to differentiate.

- They do not require any external stimuli to initiate DNA replication. They lack the G1 checkpoint in the cell cycle. ES cells spend in the $\mathrm{S}$ phase of the cell cycle their most time, during which they synthesize and form DNA. They unlike differentiated somatic cells.

- They are derived from the inner cell mass/epiblast of the blastocyst.

- They have the ability for undergoing an unlimited number of symmetrical divisions without differentiating (long-term selfrenewal).

- They exhibit and maintain a stable, full (diploid), normal complement of chromosomes (karyotype).

- They are pluripotent stem cells that can give rise to differentiated cell types that are derived from all three primary germ layers of the embryo (endoderm, mesoderm, and ectoderm).

- They have the ability for integrating into all fetal tissues during development.

- They have the ability for colonizing the germ line and giving rise to egg or sperm cells.
- They are clonogenic i.e. a single ES cell can give a colony of cells that are genetically identical having the same properties as the original cell. In the somatic cell of a female mammal, one of the two $\mathrm{X}$ sex chromosomes becomes permanently inactivated. $\mathrm{X}$ inactivation does not occur in non-differentiated embryonic stem cells.

- In the somatic cell of a female mammal, one of the two X sex chromosomes becomes permanently inactivated. X inactivation does not occur in non-differentiated embryonic stem cells.

Derivation of human embryonic stem cells: The isolation of embryonic stem cells from human blastocysts was in 1994 was the first documentation [52]. Since then, techniques of deriving and culturing human ES cells have been refined [50,53]. The isolation ability of human ES cells from blastocysts and growing them in culture depend on the integrity and condition of the blastocyst from which the cells are derived. Generally, the yield of ES cultures is most efficiently in case of blastocysts with a large and distinct inner cell mass [54].

After a fertilization of human oocyte by a sperm in vitro, some events occur according to a fairly predictable timeline as showed in Figure $3[55,56]$. At 18 to 24 hours after in vitro fertilization of the oocyte is considered the first day. By the second day (24 to 25 hours), the fertilized egg (zygote) undergoes the first cleavage to produce a two cell embryo. By the third day ( 72 hours), the embryo progresses into 8-cell stage (morula), in which the genome of the embryo starts controlling the morula development. By the fourth day, the compaction process occur in where, the cells of the embryo tightly adhere to each other. By the fifth day, the blastocyst cavity is completed. The inner cell mass begins to separate from the outer cells giving the trophectoderm which surrounds the blastocyst. This represents the first observable sign of cell differentiation in the embryo [57].

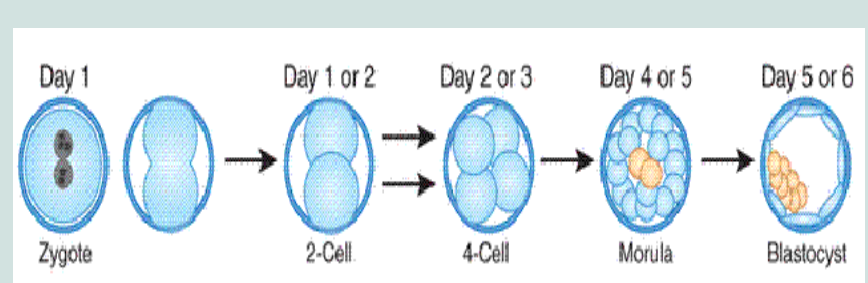

Figure 3: Timeline of stages from zygote to blastocyst [57].

The fifth day blastocysts are used to derive ES cell cultures. The normal human embryo in vitro on the fifth day is consists of 200 to 250 cells. Most of the cells comprise the trophectoderm. The trophectoderm is removed for deriving ES cell cultures, either through microsurgery or immune surgery in which the trophectoderm break down by using antibodies against it, helping free the inner cell mass, which consists of 30 to 34 cells only [58].

The conditions for growing a human embryo to the blastocyst stage in vitro vary among IVF laboratories, and are reviewed elsewhere [59-63]. However, by obtaining the inner cell mass, the techniques for growing ES cells are similar in case of mouse or human blastocysts [64]. 
Citation: Ahmed OM, Sayed HM. Stem Cell Therapies in Regenerative Medicine and Diabetes Mellitus: Advances, Constraints and Future Prospects. J Transplant Stem Cel Biol. 2016;3(1): 22.

ISSN: $2374-9326$

Table 1: Reported differentiated cell types from mouse embryonic stem cells in vitro.

\begin{tabular}{|l|l|}
\hline Cell Type & Reference \\
\hline Pancreatic islets & {$[65]$} \\
\hline Endothelial cell & {$[66,67]$} \\
\hline Hepatocytes & {$[68]$} \\
\hline Dendritic cell & {$[69]$} \\
\hline Adipocyte & {$[70]$} \\
\hline Astrocyte & {$[71]$} \\
\hline Cardiomyocyte & {$[72,73]$} \\
\hline Chondrocyte & {$[74]$} \\
\hline Definitive hematopoietic & {$[75,76,77]$} \\
\hline Keratinocyte & {$[78,67]$} \\
\hline Lymphoid precursor & {$[79]$} \\
\hline Mast cell & {$[80]$} \\
\hline Oligodendrocyte & {$[81,82]$} \\
\hline Osteoblast & {$[83]$} \\
\hline Striated muscle & {$[84]$} \\
\hline Smooth muscle & {$[67]$} \\
\hline Neuron & {$[85,86,87]$} \\
\hline Primitive haematopoietic & {$[72,75]$} \\
\hline Yolk sac endoderm & {$[72]$} \\
\hline Yolk sac mesoderm & {$[72]$} \\
\hline Stomach tissue cells & {$[88]$} \\
\hline & \\
\hline & {$[107$} \\
\hline
\end{tabular}

Human embryonic germ (EG) cells: EG cells are cells derived from precursors of germ cells from early fetal tissue [89]. These cells derived by separation of primordial germ cells that can give rise to $E G$ cells in culture as in Figure 4, that are capable of differentiating into cells of multiple lineages [89] from the somatic cells [90]. Primordial germ cells have a unique character, this character is that these cells can make generations in a successive way, but the somatic cells lack this ability because they start to differentiate [91].

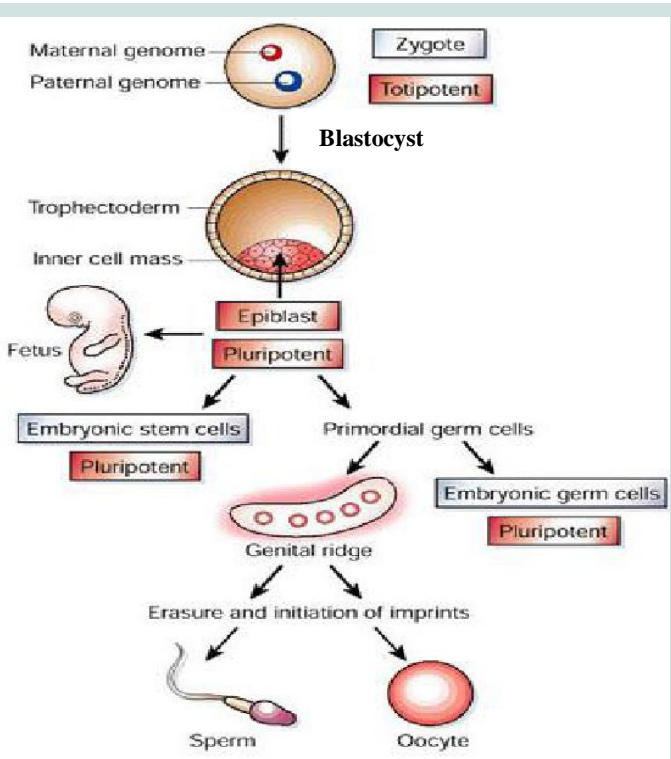

Figure 4: The embryonic germ cells derived by separation of primordial germ cells [92] with permission from the Rights Link.
Human embryonic stem cells and embryonic germ cells pluripotency: Pluripotent stem cell is a cell that is capable of selfrenewal and of differentiating into most all of the body cells, including cells of all three germ layers ectoderm, mesoderm and endoderm. Human ES and EG cells in vitro have the ability of long-term selfrenewal, while retaining a normal karyotype [4,53,93-95]. Human ES cells can proliferate for two years through 300 population doublings [96] or even 450 population doublings. Cultures have less capacity for proliferation when derived from embryoid bodies generated by human embryonic germ cells; most of them will proliferate for 40 population doublings; the maximum is 70 to 80 population doublings [95]. Several laboratories have stated that human ES cells in vitro are pluripotent; they can produce cell types derived from all three embryonic germ layers [53,94,97-99]. The injection into immune deficient mice was the only in vivo test of the pluripotency of human ES cells they generate differentiated cells that are derived from all three germ layers. These include lung, airway and gut epithelium as well as hepatocytes which is derived from endoderm; smooth and striated muscle derived from mesoderm; and neural epithelium, and stratified squamous epithelium derived from ectoderm $[4,53,97,100,101]$.

\section{Amniotic epithelial cells}

Stem cells isolated from amniotic fluid are pluripotent stem cells like ESCs. The developing embryo is known to shed a variety of cells into the surrounding amniotic fluid. From the amniotic membrane in human placenta, amniotic epithelial cells (AECs) can be derived (Figures 5a and 5b). These embryonic stem cell-like cells express the markers that are present on pluripotent ESCs and EGCs, such as Oct4, Nanog, and alkaline phosphatase. AECs also express cell surface antigens known to be expressed on other stem cells such as SSEA-3, SSEA-4, TRA 1-60, and TRA 1-81. Some surface markers such as CCR4- and CD117-positive cells are very rare while others such as CD9, integrin $\alpha 6$, and integrin $\beta 1$ are expressed on virtually $100 \%$ of the cells. They can also differentiate as ESCs and EGCs in the cell lineages from three germ layers, including pancreatic endocrine cells and hepatocytes (endoderm), cardiomyocytes (mesoderm), and neural cells (ectoderm) in vitro [102-104].

Amniotic fluid stem cells were credited with being a safer alternative to hESCs, because their proliferation rate is without loss of pluripotency or teratogenic potential when transplanted in immunodeficient animals [102,105,106]. Because AECs are abundantly available without ethical concerns and because of the advantages of pluripotency, low immunogenicity, and lack of tumorigenicity, they may be an extremely useful cell source for transplantation and organ and tissue regeneration in comparison with ESCs and induced pluripotent adult cells [107]. Thus, these embryonic stem cell-like cells could therefore provide an alternative source of cells for regenerative medicine.

For isolation of amniotic epithelial cells according the procedure of Miki and Strom [107], amnion is easily stripped from the underlying chorion and deciduas at the coarse intermediate layer of connective tissue (Figure 5a). The thin, nearly transparent amnion membrane, which contains AE cells and mesenchymal fibroblasts is obtained after several washing steps to remove blood. Amniotic membrane is trypsinized, to release the $\mathrm{AE}$ cells from the supporting connective tissue and the mesenchymal fibroblasts. 
Citation: Ahmed OM, Sayed HM. Stem Cell Therapies in Regenerative Medicine and Diabetes Mellitus: Advances, Constraints and Future Prospects. J Transplant Stem Cel Biol. 2016;3(1): 22.

\section{ISSN: $2374-9326$}

Placenta, the source of $\mathrm{AE}$ cells, is abundantly available as a discarded tissue and is free of the ethical concerns of other stem cells. Banks of AE cells could be established which contained a precise major histocompatibility complex that matches for every possible transplant recipient without the need for extensive technical manipulations such as somatic nuclear transfer. Thus, the amniotic epithelium-derived stem cells may be an extremely useful cell source for transplantation and organ and tissue regeneration [105-107].

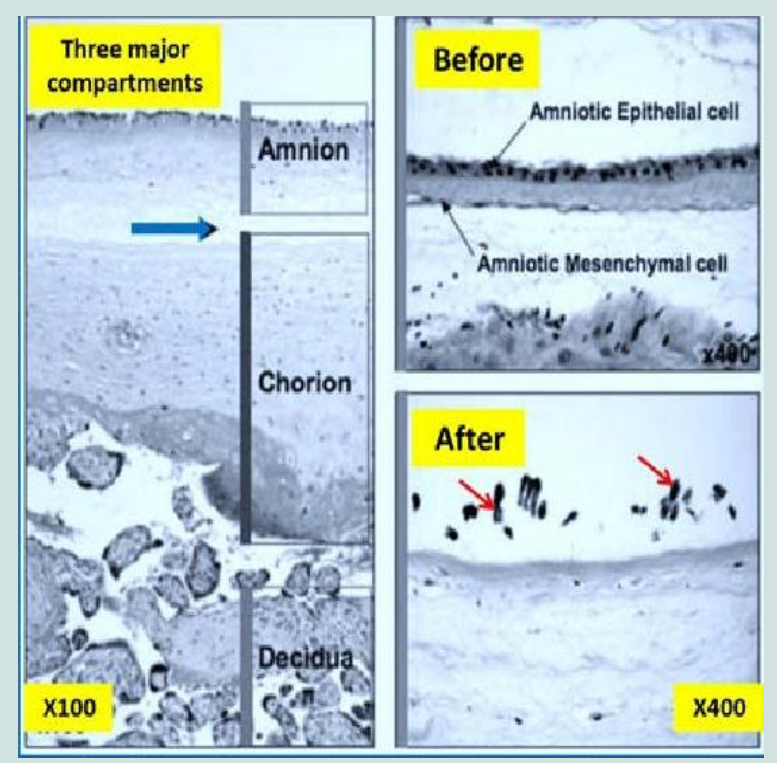

Figure 5a: Sections of normal human placenta [107]. In the left panel, the three major components, amnion, chorion, and decidua, were observed The blue arrow refers to the coarse intermediate layer of connective tissue. The right panel depicts photos of membrane before and after trypsinization. Only amniotic epithelial cells (red arrows) were dissociated by trypsinization. Subsequent collagenase digestion would release the amniotic mesenchymal cells from the adjacent connective tissue [107]

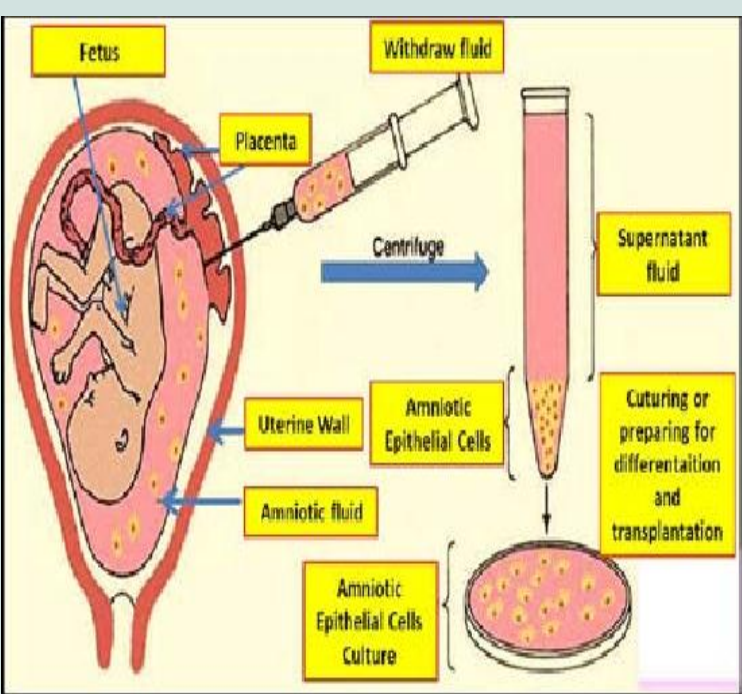

Figure 5b: Amniotic fluid stem cells isolations and their applications.

\section{Umbilical cord blood stem cells}

Umbilical cord blood (ucb) (Figure 6) was recognized, in the late 1980s, as an important clinical source of human stem cells $[108,109]$. The umbilical cord and placental blood is a good source of hematopoietic stem cells, and these cells are typically discarded with the after birth with no morbidity or harmful effects on both new born and mothers. Several approaches have been tested to overwhelm the cell dose issue, including, with some success, pooling of cord blood samples [109-112]. Cord blood stem cells have been used in routine clinical practice for the past 20 years. Cord blood stem cell technology has many advantages over embryonic and other adult stem cells for several reasons [106,113 115], including the following:

1. Cord blood represents a potentially unlimited source of stem cells that can in theory be collected at every birth.

2. Cord blood is relatively simple to process and store using tried and tested technology and, once frozen in liquid nitrogen, is biologically stable.

3. The collection of cord blood is a non-invasive procedure with no danger to either baby or mother. If cord blood is not collected, it is discarded as biological waste.

4. Cord blood carries low risk of infection.

5. When transplanted, the cord stem cells show low immunogenicity and can even have localized immunosuppressive functions.

McGuckin et al. reported the world's first reproducible production of cells expressing embryonic stem cell markers, cord-blood-derived embryonic-like stem cells, which can be maintained for 6 weeks and subcultured for a minimum 13 weeks [113].

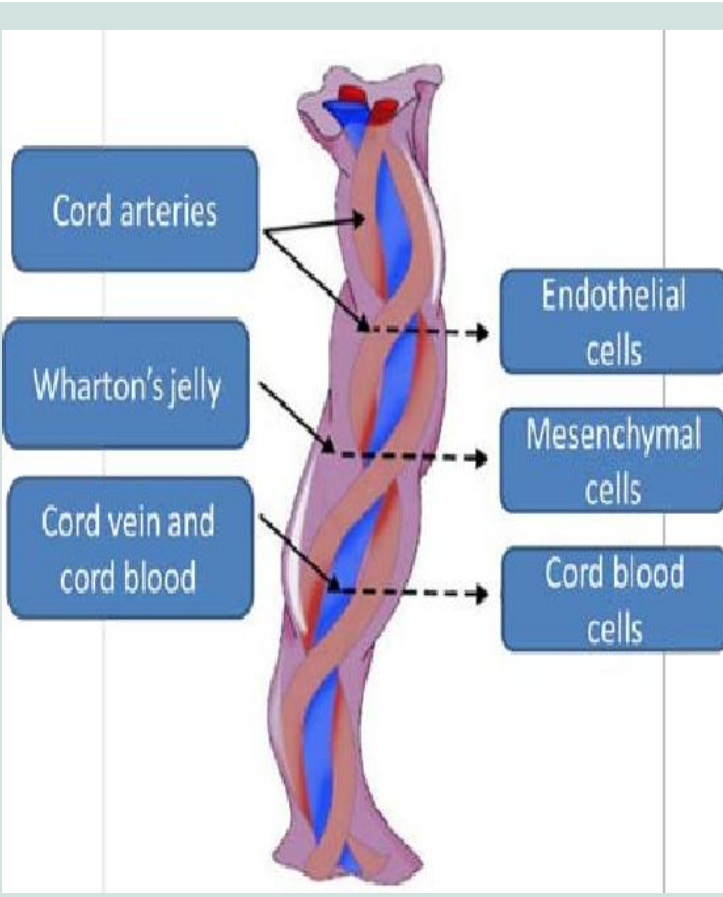

Figure 6: Umbilical cord blood stem cells [116]. 


\section{Adult stem cells}

Adult stem cells is derived from developed tissues regardless of the age of the organism at the time and they are also referred to as adult stem cells (ASC), they are multipotent and have more limited potential to differentiate into different types of cells [23]. Like all stem cells, they have two characteristics at least. First, they can make identical copies of themselves for long time periods; this proliferation ability is referred to as long-term self-renewal. Second, they can give rise to mature cell types that have morphological characteristic (shapes) and the functions are specialized. Stem cells generate, an intermediate cell type or types before their fully differentiation; these intermediate cells are called precursor or progenitor cells which have the ability to divide and give rise to differentiated cells. Their primary functions are to maintain the steady state functioning of a cell called homeostasis and, to replace cells that die with limitations [117-119]. Rather, adult stem cells are defined by their functional properties including high proliferative potential, substantial self-renewal capacity and ability to differentiate into at least one type of mature functional progeny [112,119-121]. However, there are several reasons that make ASCs are less attractive than ESCs as sources for research and therapeutic application $[47,106,122]$. These reasons include:

1. It is difficult to isolate and derive stem cells from adult tissues.

2. The cells are rare i.e. they are found in few numbers in tissues.

3. It is difficult to keep adult stem cells proliferating in culture.

4. To date, it appears that cultured adult stem cells give rise to only a limited number of cell types -they cannot be pluripotent like embryonic stem cells.

5. As they are found in adults, ASCs have been exposed to a lifetime of environmental toxins and have also accumulated a lifetime of genetic mutations.

Mesenchymal stem cells: Human adult mesenchymal stem cells (MSCs) are non-embryonic, non-hematopoietic, adherent fibroblast-like cells with intrinsic ability of self-renewal and potential for multilineage differentiation [119]. MSCs represent a population of multipotent adult stem cells that can be isolated from many tissues; most commonly bone marrow, adipose tissue and skin $[123,124]$. MSCs exhibit a number of properties that make them ideal. The MSCs populations of are strongly adherent, therefore can be isolated by culturing marrow on a specific substrate and washing other cells off. MSCs can give many kinds of cells of the connective tissue responsible for remodeling of cartilage, bone, fat, and vascular tissue $[125,126]$. MSCs can take part in maintenance of the essential microenvironment necessary to support the hematopoietic stem cells in the bone marrow [127]. MSCs can be also isolated from circulating blood [128], as well as from diverse non hematopoietic tissues such as synovium [129], trabecular bone [130], adipose tissue [131], dental pulp [132], dermis [133], and the lung [134]. MSCs, derived in vitro, express a panel of characteristic surface markers such as $\mathrm{SH}-2$ endoglin (CD105), SH-3/4 (CD73), b-1-integrin (CD29), Thy-1 (CD90) and CD44; and are negative for hematopoietic markers such as CD14, CD34 and CD45 [106].
Hematopoietic stem cells: Hematopoietic stem cells are the early precursor cells that give rise to all cell types of the blood including both the myeloid (macrophages and monocytes, basophils, neutrophils, eosinophils, erythrocytes, megakaryocytes/platelets and some dendritic cells) and lymphoid (B-cells, T-cells, NK cells, some dendritic cells) (Figure 7). Hematopoietic stem cells have the ability to generate all the blood cells and can restore the bone marrow after depletion due to disease, chemotherapy or irradiation $[106,135,136]$. Hematopoietic stem cells have specific morphological appearances and cell-surface markers that allow them to be labeled and tracked in the blood flow and goal tissues or to be isolated and cultured in laboratory. Hematopoietic stem cells represent less than $0.05 \%$ of the whole bone marrow, but they have the potential to reconstitute all blood forming lineages [105]. Because of their enormous clinical implications of such ability, the hematopoietic stem cells have historically been the best characterized stem cell niche [112].

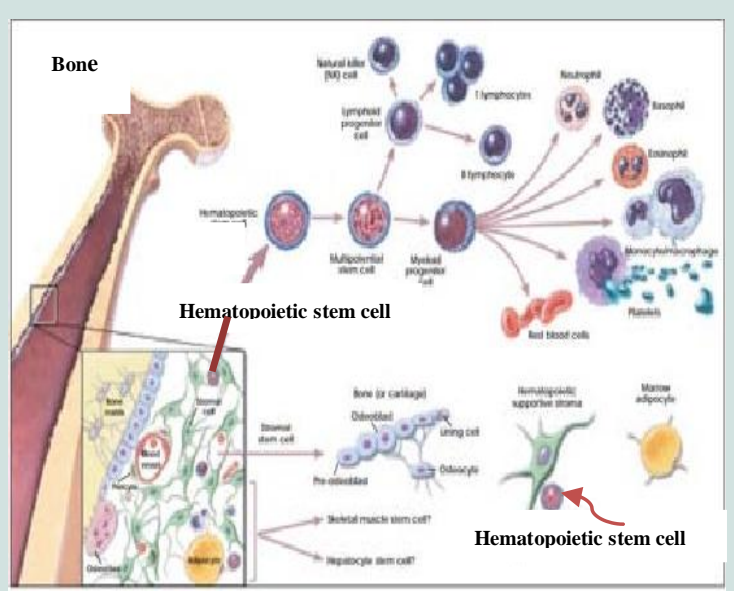

Figure 7: Hematopoietic stem cells [137].

Neural stem cells: Neuronal stem cells (NSCs) have been isolated from the brains of adults and embryos. Neural stem cells can be identified as cells that can self-renew in continuous way and have the ability to generate intermediate and mature cells of both glial and neuronal lineages $[138,139]$. Adult neural stem cells have the ability to differentiate into multiple cell types of the brain as mainly astrocytes, oligodendrocytes, and neurons and used in transplants for Parkinson's disease. In vitro, they are able to differentiate into the 3 major neuro ectodermal lineages (neurons, astrocytes, and oligodendrocytes) [140]. These cells that have been produced have major therapeutic advantages such as those used in transplants for Parkinson's disease. Furthermore, these neural stem cells when injected into blastocysts of mice, they contributed to form multiple types of tissues in the embryos; so, they are multipotent stem cells [141]. One study reported the generation of blood from neuronal stem cells when transplanted into lethally irradiated recipients, but this has not yet been reproduced [142]. When these neuronal stem cells cultured with a cell line capable of differentiating into muscle or when injected into regenerating muscle, they have also been observed to grow into skeletal muscle [143]. In brain-injury models, NSCs proliferate into cells of neurogenic regions and are able to migrate and evenly directed toward the site of damage [106]. 
Pancreatic stem cells: It is well known that the pancreas of adult mammalians has three tissue types. The $1^{\text {st }}$ is the endocrine islets of Langerhans, composed of $\beta$-cells, which produce insulin hormone, $\alpha$-cells that produce glucagon hormone, $\delta$-cells that produce somatostatin hormone, and pp-cells that produce pancreatic polypeptide. The $2^{\text {nd }}$ is the ductal tree and the $3^{\text {rd }}$ is the exocrine acini that produce the pancreatic juice containing digestive enzymes (Figure 8). Furthermore, the progenitor cells which are multipotent and have been identified within islets and the ducts in adult rodent and human pancreas $[144,145]$. The multipotent pancreatic stem cells (PSCs) that were isolated from the human fetal pancreas were able to be express stem cell markers and form the islet like cell clusters (ICCs) when cultured ex vivo [146]. They express stem cell markers, such as nestin, ATP binding cassette transporter (ABCG2), and KIT, as well as epidermal growth factor receptor (EGFR), hepatocyte growth factor receptor (c-Met), and glucagon-like peptide receptor. Type 1 diabetes results from destruction of cells in pancreatic islets, can be reversed by transplantation of ICCs [147], because these cell clusters can give rise to diverse pancreatic cell lineages, including insulin-secreting cells [106,148]

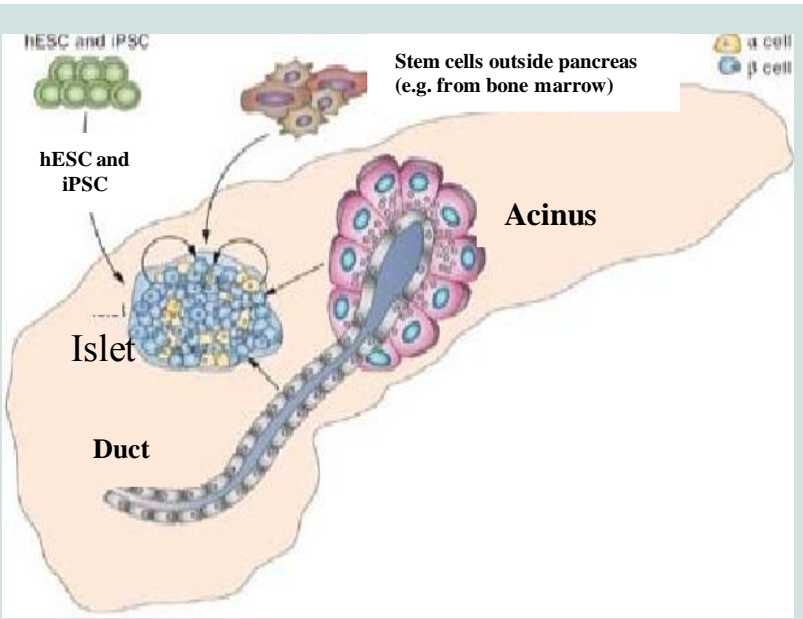

Figure 8: The use of stem cells for pancreatic regeneration in diabetes mellitus [148] with permission from the Rights Link.

Skin stem cells: The principal niche of multipotent stem cells in the skin have revealed through numerous studies to be in the upper region of hair follicles and the bulge area. The small clusters of multipotent stem cells appear to reside near the basement membrane of the epidermis and express specific markers, including K15 [149]. The skin stem cells are responsible for the growth of the hair follicles for long-term and epidermis regeneration after injury [150-155]. More specifically, multipotent epithelial stem cells within the bulge area are able to proliferate and give rise to the follicular epithelium, as well as to new cells constituting IFE and sebaceous glands after severe injury $[156,157]$. In adult mammalian hair follicle, the bulge area also contains a pluripotent epidermal neural crest stem cell (eNCSC) population that shows several properties similar to embryonic neural crest stem cells [158]. The pluripotent eNCSCs in the bulge area have the ability to self-renew and give rise to multiple cell lineages in vivo, including melanocytes, neurons, Schwann cells, smooth muscle cells, and chondrocytes [158].
Like eNCSCs and under well-defined conditions, it has been observed that each individual multipotent cell from melanoma spheres was able to differentiate into multiple cell types, including melanocytes, adipocytes, osteocytes, and chondrocytes $[159,160]$. Furthermore, it was reported that multipotent cells derived from the dermis proliferate and differentiate in culture to produce both neural and mesodermal cells, including neurons, glia, smooth muscle and adipocytes [106].

Fat tissue derived stem cells: Human adipose tissue is a source of multipotent stem cells [161]. Fat tissue is abundant, having a large number of cells, and can be obtained easily with low morbidity at the harvest site [131]. The fat stem cells can be differentiated into various cell lines in vitro [106] including osteogenic [162], chondrogenic $[131,162,163]$ and neurogenic lineages [163-166]. Also, myocytes and cardiomyocytes can be obtained from fat tissue derived stem cells $[167,168]$. By using mouse adipose tissue derived stroma vascular fraction, the haematopoietic cells can be derived $[169,170]$. Fat tissue derived stem cells can be maintained in vitro for long periods of time with stable doubling in population and low levels of senescence [131]. The use of fat cells opens numerous and promising outlook in regenerative medicine.

Monocytes: Under specific culture conditions, monocytes have been shown to dedifferentiate into cells that can proliferate then differentiate into different cells including epithelial, endothelial, neuronal, islet like cells producing insulin, liver like cells producing albumin, and fat cells or return back to monocytes [171]. The ability to obtain and differentiate these monocytes which are pluripotent cells from autologous peripheral blood makes them valuable candidates for regenerative medicine.

Heart: Human heart in the adults has been shown to contain resident adult stem cells having the ability to differentiate into cardiomyocytes and coronary vessels in vivo [106,172,173]. As precursors of cardiac muscle transplantation of autologous myoblast cells and other cell types, for example, cardiomyocytes and BMderived cells have also been reported to be potential therapy for the treatment of myocardial dysfunction [174].

Induced pluripotent stem cells: At Kyoto University in Japan in 2006 , the conditions that would allow specialized adult cells to be genetically "reprogrammed" to assume a stem cell-like state were identified by researchers. These reprogrammed adult cells, called induced pluripotent stem cells (iPSCs). These cells represent the same properties of ESCs $[175,176]$ and can differentiate into cells formed from any of the three germ layers endoderm, mesoderm and ectoderm (Figure 9). Hence, it could replace the use of embryonic stem cells (ESC), and may overcome the various ethical issues regarding the use of embryos in research and clinics [177].

In 2006, it was demonstrated that stem cells with properties similar to ESCs could be generated from fibroblasts of mouse by introducing four genes simultaneously [178]. In 2007, it was reported that human fibroblasts have a similar approach which was applicable by introducing a group of factors, human iPSCs can be generated [179]. The generation of human iPSC using a different combination of factors [180] also reported by James Thomsones group. Only four transcription factors Oct4 (Octamer binding tran- scription factor-4), 
ISSN: $2374-9326$

Sox2 (Sex determining region Y)-box 2, Klf4 (Kruppel Like Factor-4), and c-Myc a was reported as required to reprogram mouse fibroblasts (cells present in the skin and other connective tissues) to an embryonic stem cell-like state by forcing them to express genes important for maintaining the properties of defining ESCs [178]. These factors were chosen because they were known to be involved in the maintenance of pluripotency, which is the capability to generate all other cell types of the body. The newly-created iPSCs were highly similar to ESCs and after several weeks they could be established in culture $[178,181]$. In 2007, two different research groups use a new different combination of genes either the original four genes to deriving iPSCs from human cells [179]. This combination contains Oct4, Sox2, Nanog and Lin28 [180]. Since then, generating iPSCs from somatic tissues of the monkey [182], rat [183,184] and humans [177] has been reported.

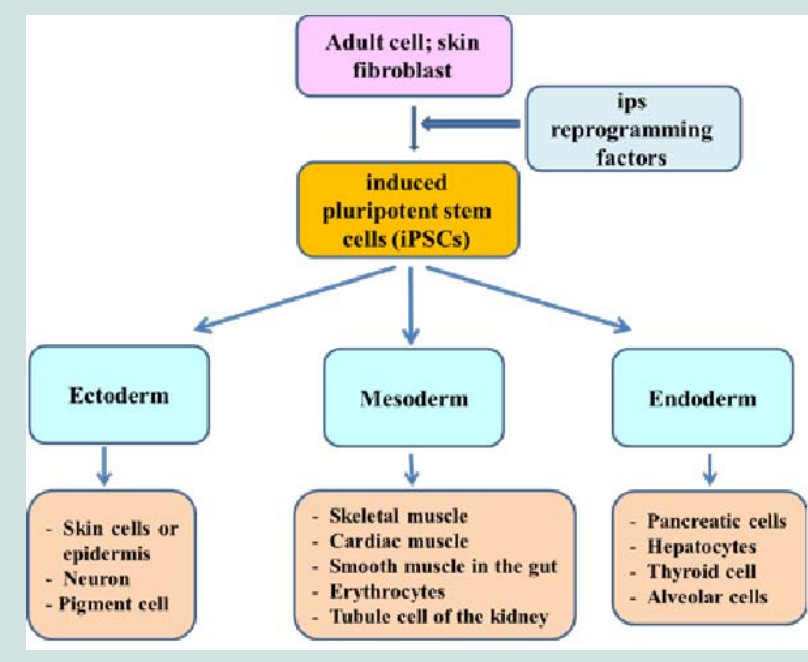

Figure 9: Induced pluripotent stem cells.

\section{Stem Cells and Regenerative Medicine}

Stem cells have been identified as clonal cells that have the capacity to self-renew as well as the ability to generate more than one type of specialized cells [185-187]. So, stem cells have the ability to create miracles. These properties make them very important in wound healing and in the regenerative medicine. The aim of regenerative medicine is repairing tissue or organs that loss their function due to injury, disease or aging by restoring the function of cells, tissues and organs faster and better. The advantage of that strategy is to obtain an autologous source of cells, which when differentiated and/or transplanted will not be rejected by the recipients. Despite the fact that more and more research are showing evidence for the potential use of stem cells in regenerative medicine [188], it is not clear which type of stem cell provides the best approach for cell therapy. Zare et al. reported that embryonic and adult stem cells can be used for treating some degenerative diseases such as age-related functional defects, hematopoietic and immune system disorders, heart failures, chronic liver injuries, diabetes, Parkinson's and Alzheimer's diseases, arthritis and muscular, skin, lung, eye, and digestive disorders as well as aggressive and regressive cancers [106].

\section{Embryonic stem cells in regenerative medicine}

Human embryonic stem cell (HESC) research offers much hope for alleviating the human suffering brought on by the ravages of disease and injury. Since the discovery of hESCs in 1998 by Thomson et al. much has transpired, including ethical, political and scientific debates, with an overall push to achieve the promise of human therapies [4]. In 2014, Atala, director of the Wake Forest Institute for Regenerative Medicine in Winston-Salem, US had followed-up patients treated with hESC-derived stem cells, showing both safety and apparent efficacy [189]. There is a recent evidence of benefit following transplantation of human embryonic stem cell derived neural progenitors and cardiomyocytes into animal models of Parkinson"s disease and myocardial injury respectively [119,182,190192]. In the mouse, there is argument of concept for the use of ES cell-derived tissues to treat models of diabetes [193], Parkinson "s disease [192,194], myocardial infarction [195], spinal injury [196], and a severe genetic immune disorder [112]. There are some limitations in using ESCs as destruction of embryos to isolate human embryonic stem cells (hESCs) is considered a major ethical concern regarding the use of these cells [197]. Another limitation is the allogenic resource of these cells; thus, when transplantation is carried out, the immune rejection results and the risk of teratoma formation and possible transmission of disease may occur [23]. It was reported in the Guardian and by Schwartz and his colleagues, that nine patients with dry atrophic age-related macular degeneration and nine with Stargardt's macular dystrophy had injections of 50,000 to 150,000 retinal pigment cells behind the retina of their worst-affected eye $[198,199]$. The pigment cells were created in the lab by treating human embryonic stem cells (hESCs) with chemicals that make them transform into retinal cells. Schwartz and his colleagues also said that patients had tolerated the implanted cells, derived from human embryonic stem cells (hESC), for up to 37 months [199]. They found no evidence of hyper-proliferation or rejection of the implanted cells during a typical follow-up period of 22 months. Based on their results and evidences, they suggested that hESC-derived cells could provide a potentially safe new source of cells for the therapy of various unmet medical disorders requiring tissue repair or replacement.

\section{Adult stem cells in regenerative medicine}

Adult stem cells include different types, some of them are hematopoietic stem cells (HSCs), mesenchymal stem cells (MSCs), adipose tissue-derived stem cells (ADSCs), cardiac stem cells (CSCs), neural stem cells (NSCs), pancreatic stem cells (PSCs), hepatic oval cells (HOCs) and bronchioalveolar stem cells (BASCs). Adult stem cells are located within a stem cell niche and upon injury, proliferate to maintain the stable stem cell number and generate differentiated cells to replace damaged tissue cells. Adult stem cells applications in the treatment of many diseases including nervous system disorders, heart disorders, diabetes, muscular disorders, vascular disorders and interstitial lung diseases have been established [124,200].

It has been become a straight and easy forward approach for applying stem cells in the therapy and regenerative medicine by injection or transplantation of adult stem cells or differentiated cells into the targeted diseased or injured site $[124,201]$.

Bone marrow (BM) contains at least three types of stem cells: HSCs, MSCs and endothelial progenitor cells (EPCs) [202]. HSCs are able to regenerate the hematopoietic system through its ability to differentiate into all types of blood cells and MSCs are able to differentiate into skeletal tissues [203]. Currently, BM or BM derived stem cell transplantation is the best-known and well-established stem cell-based therapy in regenerative medicine. HSC transplantation 


\section{ISSN: 2374-9326}

method has been established and has become a standard therapy for the treatment of many hematopoietic diseases including Hodgkin"s and non-Hodgkin"s lymphoma, acute and chronic myelogenous leukemia and myelodysplastic syndromes [204,205]. A concept that has brought much attention recently in the field of adult stem cell research is plasticity, which describes the phenomenon that restrictions in cell fates are flexible and the capacity of stem cells to differentiate into various cell types, including those not of their lineage of origin [206]. Recently, Abo Elkheir et al. stated autologous bone marrow derived MSC therapy represent a safe therapeutic measure in ischemic stroke and intrathecal route is an effective route of stem cell administration, especially in early cases [124].

\section{Induced pluripotent stem cells in regenerative medicine}

The recent breakthrough discovery of induced pluripotent stem cells (iPS) was performed by cellular reprogramming of mature/adult cells [207]. With the discovery of induced pluripotent stem (iPS) cells, it is now possible to convert differentiated somatic cells into multipotent stem cells that have the capacity to generate all cell types of adult tissues [208].Thus, there is a wide variety of applications for this technology, including regenerative medicine.

In regenerative medicine, the degenerated or injured tissues are repaired by the generation of those tissues with the help of iPSCs in labs and then transplanting them to the site of injury or degeneration. The use of iPSCs offers a good approach for these therapies as the cells that will be transplanted to patient's body will be differentiated from the repaired iPSCs generated from the somatic cells from patient's own body. The iPSCs have been used in treating a number of injuries and degenerative diseases [177]. The RIKEN Center for Developmental Biology in Kobe, Japan, announced the treatment of the very first patient with induced pluripotent stem cells-the indication was macular degeneration [209]. Different other injuries as a result of human activities, accidents or natural calamities can also be treated by the gene therapy utilizing iPSCs. The various conditions that can be treated are hematopoietic disorders, musculoskeletal injury, spinal cord injury, liver damage by the generation of specific cells with the help of iPSCs [210-213]. There are various techniques by which iPSCs can be used for the production of RBCs [214]. Furthermore, iPSCs can also be used for the generation of various cells which can help in the repairment of many tissues, for example, cardiovascular cells for the repairment of heart valves, vessels and ischemic tissues [215,216]. However, much work remains to be done before induced pluripotent stem cell therapies go beyond regulatory trials, but the path is now set in motion.

\section{Stem Cells and Diabetes Mellitus}

The treatments of diabetes mellitus with exogenous insulin and anti-diabetic conventional chemical drugs lead to temporary improvement of the diabetic conditions [217]. Moreover, both pancreas and islet transplantation require lifelong immune suppression to prevent graft rejection and recurrence of the autoimmune processes that might again destroy pancreatic islet- cells [218]. Thus, intensive research is being conducted to look for alternative therapies. There are extensive studies to develop long acting therapies of this disease by transplantation and injection of stem cells (Figure 10). Embryonic stem cells [219], adult stem cells [201], stem cells electrofused with pancreatic islet's cells [7,220] and adult somatic cells trasdifferentiated into pancreatic $\beta$-cells by direct reprogramming [221,222], all are applied in regenerative medicine of diabetes mellitus.

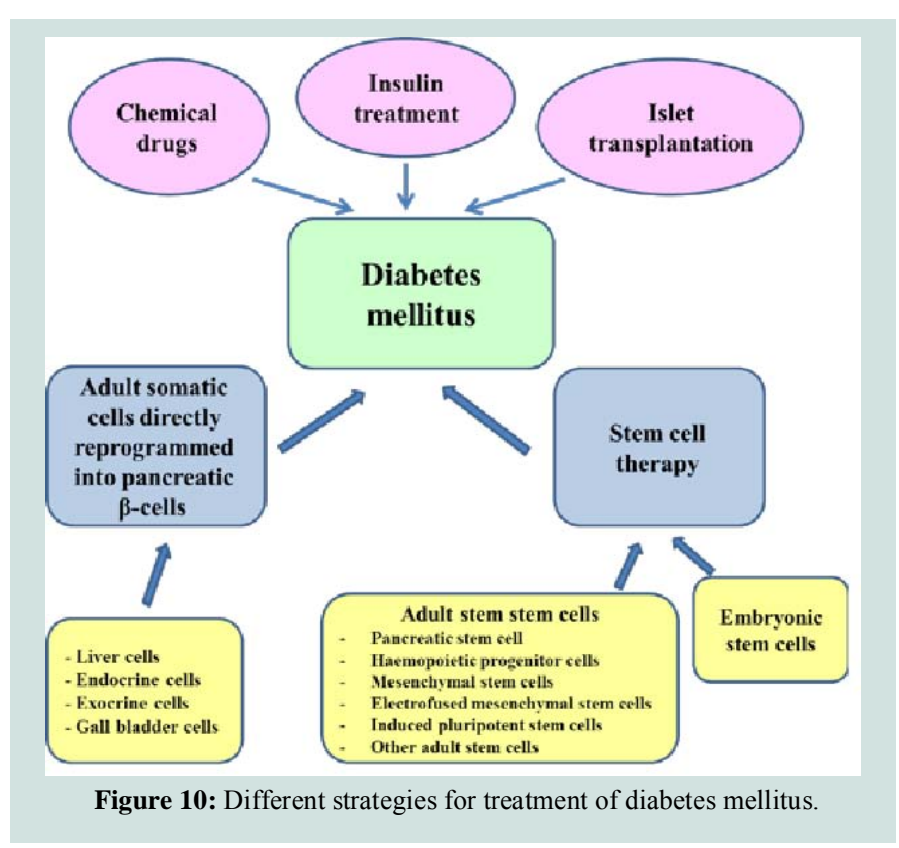

\section{Embryonic stem cells and diabetes mellitus}

The pluripotent ESCs are explored for their use in a number of medical conditions, including diabetes [223]. The discovery of methods to isolate and grow human embryonic stem cells in 1998 renewed the hopes of researchers, doctors, and diabetes patients and their families that a cure for type 1 diabetes and perhaps type 2 diabetes as well, may be within striking distance [219]. ESCs are noticed as an excellent resource for insulin secreting islet cells generation [119]. It is possible theoretically, despite the difficulties, that ESCs could be directed to differentiate into pancreatic islet cells and these cells could then be implanted in patients with diabetes, thus the $\beta$-cell deficit could be repealed [201]. Over a decade ago, pancreatic islet cells were produced from mouse ESCs [224]. The ESCs, derived from inner cell mass of mouse blastula, were differentiated in vitro into pancreatic islets "e cells that able to synthesize and secret insulin in response to an increasing glucose concentration as depicted in Figure 11. These cells were transplanted into diabetic mice and resulted in the amelioration of hyperglycemia for few months [38]. A number of other groups of researchers have also utilized both mouse [65,225-228] and human [37,229]. ESCs, in these studies, have different degree of success in producing islets. All these efforts have come across different issues that include final cell homogeneity [65], low numbers of insulinproducing cells [230], immaturity of the differentiated cells [229] and a poor insulin response when the cells were exposed to glucose [37,231]. In 2008, a robust and efficient method to establish mouse ES cells was reported by Ying et al. which are also applicable to establish rat ES cells [51,232].

Few groups of researchers also argued that as these cells could not produce C-peptide and intracellular insulin once the cells were cultured in insulin-free medium, they were not actually insulin producing cells [233-235]. Despite, it was proving difficult to make reliable insulin-producing $\beta$-cell phenotype from ESCs. Collectively, all these issues make the researchers to stop and rethink their differentiation strategies and a recipe to convert mouse ESCs into definitive endoderm has been developed by Kubo et al. [236]. In 2005 , D Amour et al. redefined protocol to produce approximately $100 \%$ pure definitive endodermal cell population [237]. The same 
ISSN: 2374-9326

group had illustrated the production pancreatic endocrine cells that secrete insulin and C-peptide by a five stage in vitro differentiation process [238]. Later, Kroon et al. achieved this response as the hyperglycemic responsiveness is a crucial characteristic that is needed for any potential cellular diabetic therapy [239]. These unique differentiated cells that resemble 6-9 week-old embryo have been transplanted into the immune deficient mice and showed that the insulin release was glucose dependent. This allowed the cells to recover mice from STZ (streptozotocin)-induced diabetes as well as to prevent it [239]. By modifying the differentiation protocols and using genetically modified embryonic stem cells (mES), two groups successfully generated insulin-producing cells [227,228]. Blyszczuk et al. showed that constitutive expression of the pancreatic developmental control gene Pax4 and histotypic differentiation were essential for the formation of insulin expressing cells, which were found to contain secretory granules typical of both adult and embryonic $\beta$-cells [227]. Importantly, these cells coexpressed Cpeptide and improved blood glucose levels to normal levels after transplantation into diabetic mice [227,240]. Similarly, lineage selection using mES cells transfected with a plasmid containing the Nkx6.1 promoter upstream of a neomycin- resistance gene could be used to generate insulin-producing cells that normalized glycemic state after transplantation into diabetic animals [228]. Also treatment of mES cells with a phosphoinositide 3-kinase (PI 3-K) inhibitor during terminal stages of differentiation generated ES cell progeny expressing various $\beta$-cell specific markers. Following engraftment into diabetic mice, these cells also alleviated the glycemic status and enhanced animal survival [225].

More recently, hESCs can be induced to differentiate into fetallike pancreatic islet's cells in vitro using a 33-day, 7-stage protocol [241]. In this protocol, inducing hESCs into $\beta$-cells involves activation of Wnt (Wingless-related integration site) and transforming growth factor $\beta$ (TGF $\beta$ ) signaling pathways [242-244]. Fibroblast growth factor (FGF) 10, activin and retinoic acid are used to induce the differentiation of hESCs into Pdxl (Pancreatic and Duodenal Homeobox1 expressing cells) [245-247]. Other markers used to identify definitive endoderm include Sry related HMG box-2 (SOX17), Fibroblast Growth Factor (FGF) 7, Forkhead Box Protein A2 (FoXa2), brachyury protein, $\mathrm{CXC}$ - chemokine receptor $(\mathrm{CXCr})$ 4 and Cerberus [248-252]. Definitive endoderm 1 and 2 (iDe1 and iDe2) have been demonstrated to induce the construction of ultimate endoderm from mouse and human ESCs with about 70-80\% efficiency, which is much higher than the differentiation induced by nodal or activin $[253,254]$. The next in vitro step is to reproduce the formation of the pancreatic dorsal anlage. This step is dependent on simultaneous retinoic acid signaling and inhibition of Hedgehog signaling, both of which have been effectively reproduced [255]. Activina in conjunction with Wnt3a, as well as iDe1 and iDe2 in combination with FGF10 are capable of inducing development of endoderm cells into pancreatic progenitors in vitro [256]. Indolactam $\mathrm{V}$ stimulates protein kinase $\mathrm{C}$ signaling after treatment with Wnt3a, FGF10, activina, cyclopamine and retinoic acid and results in induction of pancreatic progenitor cells expressing Pdx1 with about 50\% efficiency [257-259]. The miR- 375 has a critical role in early development since miR-375 is highly expressed in definitive endoderm and regulates expression of Pdk1 and Myotrophin (Mtpn) genes. Thus, the controlling of the expression of microRNAs (miR)-375 could assist mature hESCs-derived $\beta$-cells [260,261]. As reported by Cai et al. hESCs have been differentiated into cells capable of synthesizing insulin, glucagon, somatostation, ghrelin and pancreatic polypeptide [262]. Therefore, hESCs represent a novel alternative source for generative medicine and targeted replacement therapies for diabetes mellitus. The hESC cell line, PKU1.1, can be induced to differentiate into insulin-producing cells (IPCs) [263] containing insulin similar to that of human islets, but these derived cells lack the main function of glucose-stimulated insulin secretion in vitro. However, hESCs have been shown to secrete insulin in response to glucose after transplantation into immune deficient mice [264]. The final stages of differentiation to derive functionally mature $\beta$-cells from hESCs must occur in vivo [265]. These discoveries may lead the way for ESCs to become a strong applicant for cellular replacement therapy in T1DM and in type 2 diabetes mellitus (T2DM) with subsequent damage in $\beta$-cells as a result of persistent hyperglycemia and hyperlipidemia in the near future. Although much progress has been made in this area, there are still important issues to be addressed before this treatment is widely applicable, including difficulties in maintaining insulin independence, low success rates of islet isolation, multiple donor requirements, and side effects associated with the use of immunosuppressants.

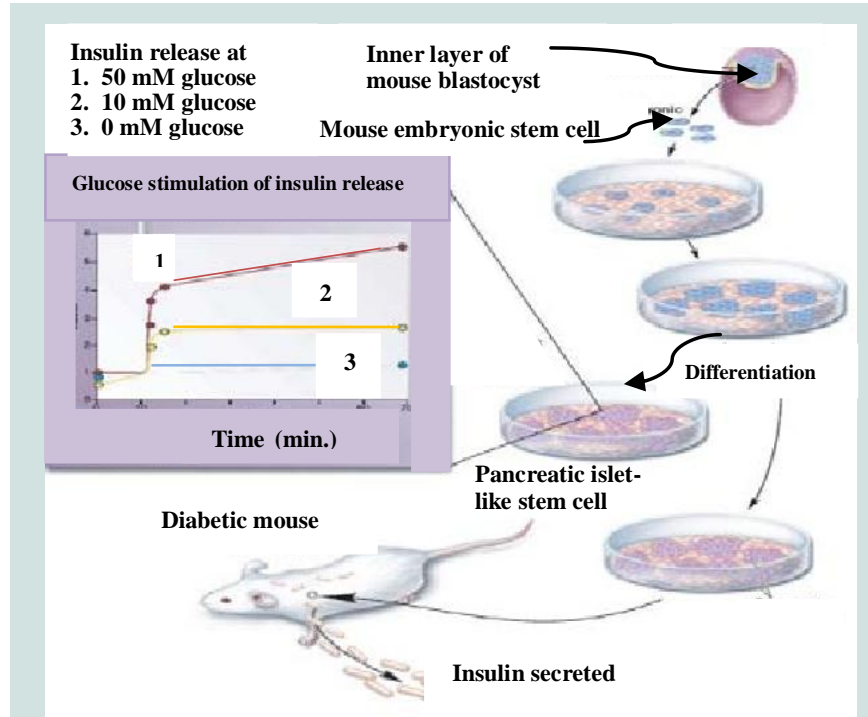

Figure 11: Development of insulin-secreting pancreatic-like cells from mouse embryonic stem cells [223].

\section{Adult stem cells and diabetes mellitus}

Pancreatic stem cells: The pancreas is an organ of first choice to be looking for the potential stem cells. The animal research has shown that the availability of small amounts of pancreatic tissue would restore the maximum pancreatic $\beta$-cell mass [266]. This is due to the replication of differentiated $\beta$-cells of pancreatic ducts and dedifferentiation of these cells to pluripotent cells that in turn produce more $\beta$-cells. In vitro, the population of ductal cells could be cultivated and directed to form insulin producing clusters [267,268]. In 2004, Seaberg et al. developed from ductal cells, a clonal population of adult pancreatic precursor cells that can produce both C-peptide and insulin [144]. Furthermore, it is believed that the pancreatic duct, acinus and islet are derived from pancreatic duct epithelial cells after birth. Therefore, pancreatic duct epithelial cells are assumed to represent the main source of stem cells for pancreatic regeneration [201].

The islets of both rodent and human contain multipotent stem cells $[269,270]$. In the past, many researchers raised their speculation about the existence of pancreatic adult stem, despite the progress and 
ISSN: $2374-9326$

promise of pancreatic stem cells [271]. In 2008, Xu et al. have provided the existence of multipotent progenitor cells in the pancreatic ducts of mice which can give new $\beta$-cells [272]. The research proves two facts, the first one is the existence of pancreatic stem cell and the second is that $\beta$-cells can be formed from non- $\beta$-cells.

Recently, it was reported that when the transcription factors MafA, Pdx1, Paired Box Protein 4 (Pax6) and Neurogenic Differentiation Factor 3 (Neurog3) were co-expressed through an adenovirusmediated transgenic system, CD133 plus cells cultured into spheres and had greatly enhanced insulin gene expression [201]. Importantly, when transplanted into NOD scid gamma mice, the progeny of the CD133 plus cells showed insulin release in a glucose dependent manner and circulating human insulin was detected in the serum of host mice [273]. These results suggest that CD133 positive pancreatic duct cells could potentially be used inhuman $\beta$-cell regeneration therapy if new strategies for safer expansion and differentiation are developed.

In future, further research needs to focus on finding and activating pancreatic stem cells in diabetic patients to promote $\beta$-cell formation. More research strategies are required to develop suitable methods to address the issue of isolation and ex vivo expansion of these stem cells for transplantation.

Haemopoietic progenitor cells: Various groups of researchers explored the multipotent differentiation of haemopoietic progenitors to regenerate the $\beta$-cell population in T1DM. In vivo experiment, the mouse bone marrow-derived cells were differentiated into functionally competent $\beta$ - cells [274]. Similar experiments with mice showed that bone marrow-derived cells can be targeted to the pancreas and that hyperglycemia can be altered [275]. Autologous HSCs studies that carried out showed improvement in both type 1 [18] and type 2 diabetes mellitus [276]. Bone marrowderived stem cells (BMSCs) have the ability to differentiate into $\beta$-cells [201]. It was reported that when human BMSCs were transplanted into NOD/scid mice with streptozotocin-induced pancreatic damage, enhanced insulin secretion and reduced hyperglycemia was produced [277]. Thus, these studies provide promising results for the use of HSCs in the diabetes treatment.

Mesenchymal stem cells: Mesenchymal stem cells (MSCs) can be isolated from bone marrow, umbilical cord blood, adipose tissue, and other tissues and are easily procurable [278]. MSCs have been reported to secrete factors that decrease inflammatory and immune reactions [279,280]. MSCs derived from human bone marrow have been shown to protect human islets from proinflammatory cytokines [281], and enable to differentiate into insulin producing cells in vitro. These cells have been shown to improve hyperglycemia when transplanted into diabetic mice [282].

Human adipose tissue-derived MSCs help to improve glucose levels and decrease levels of inflammatory cytokines and free fatty acids in type 2 diabetic mice due to their ability to differentiate into glucose-sensitive insulin-producing cells $[283,284]$. Vanikar et al. and Thakkar et al. reported that adipose-derived insulin-secreting mesenchymal stromal cells and bone marrow-derived hematopoietic stem cell co-infusion offers safely and effectively long-term therapy of diabetes mellitus in type 1 diabetic persons [285,286].

Easy and repeatable access of MSCs from subcutaneous adipose tissue provides a clear advantage overisolation of MSC from BM [285]. Similarly, Si et al. and $\mathrm{Xi}$ and $\mathrm{Bu}$ found that autologous MSCs transplantation in a rat model of type 2 diabetes resulted in enhanced insulin secretion increased islet numbers in pancreas and ameliorated insulin sensitivity, suggesting functional effects of autologous MSCs inoculum on insulin target tissues [7,201].

Electrofused mesenchymal stem cells: Electrofusion of MSCs with pancreatic islets cells and transplantation of the resultant fusion stem cells into pancreas to treat types 1 and 2 diabetes mellitus is recently recommended by some investigators [7,220]. This evidence was released in continuations with the findings of previous publications. Park et al. found that MSCs co-cultured with islets secrete higher levels of anti-apoptotic signaling molecules and improve glucose-stimulated insulin secretion indexes [287]. It was also revealed by Rackham et al. that co-transplantation of MSCs with islets improved the capacity of islet grafts to reverse hyperglycemia compared with islets alone [288]. This improvement may be attributed to the promotion of anti-apoptotic gene expression as suggested by $\mathrm{Lu}$ et al. Because of these favorable effects on islets, MSCs provide an important approach for improvement of islet engraftment, thereby decreasing the numbers of islets needed to achieve insulin independence $[289,290]$. In the same way, $\mathrm{Si}$ et al. showed that infusion of MSCs not only promoted $\beta$-cell function but also ameliorated insulin resistance in type 2 diabetic rats [7]. Those authors reported that infusion of MSCs resulted in an increase of GLUT4expression and an elevation of phosphorylated insulin receptor substrate 1 (IRS-1) and Akt (protein kinase B) in insulin target tissues.

Based on his experiment in streptozotocin-induced diabetic rats, Yanai et al. hypothesized that electrofusion of islet cells with MSCs is an efficient method to obtain potent and robust insulin-secreting cells that can potentially have a clinical interest since it could help to reduce the number of islet cells needed to achieve a therapeutic benefit in diabetic patients [220].

Induced pluripotent stem cells and diabetes: Induced pluripotent stem (iPSCs) cells have potential applications in regenerative medicine for diabetes [201]. The iPSCs are adult somatic cells which are reprogrammed back to the pluripotent state [291] These iPSCs are preferred choices of cell based therapy for diabetes management as they can be patient specific and eliminate the possibility of rejection. Induced pluripotency is achieved by directed expression of specific transcription factors [292]. The iPSCs exhibit high telomerase activity similar to that of ESCs and possess hypomethylated gene promoters [179,293]. The fibroblast cells are induced to produce iPSCs and these cells are later converted to pancreatic beta like cells by a three-stage differentiation process. The transplantation of fibroblast derived beta like cells in diabetic mouse model was effective in controlling hyperglycemia for long term [294]. The human ESCs and iPSCs were differentiated into mature pancreatic cells that were capable of secreting both insulin and C-peptide [295]. The fibroblastic cells of type 1 diabetic patient were induced to produce pluripotent stem cells and the produced cells are identified as insulin secreting cells [296]. These research innovations and recent progress in induced pluripotency field would allow the usage patient-specific iPSCs for cell based therapies in diabetes. The safe usage of iPSCs for diabetes management must be secured as these cells exhibit irregular behavior and important variations in reprogramming [297]. 
Other adult stem cells: Many other stem cell resources have been explored for the production of insulin secreting $\beta$-cells and different degrees of success have been achieved. The resources include the stem cells of the small intestine [298,299], salivary glands [300] and adipose tissue [301]. In the years to come, the hepatic production of insulin has the potential to become a viable source for $\beta$-cell replacement This is possible after addressing the practical hurdles associated with these cell lines, culture conditions, complete differentiation, and islet structure formation.

\section{Direct Reprogramming of Hepatocytes and other Adult Somatic Cells to Pancreatic B-Cells for Cell Therapy of Diabetes}

The direct conversion of one cell type to another without an intermediate pluripotent stage is recently considered as a potential source of transplantable differentiated cells in regenerative therapies. The ventral pancreas and liver share a common developmental origin as they are derived from endoderm and have an edge over others [221,222]. Different research groups have successfully transdifferentiated rodent hepatic cells into pancreatic $\beta$-cells, insulin-producing cells, via multiple genetic approaches [301-305]. Improvement of hyperglycemia was achieved by these cells in the mouse models [306]. It was also reported that intrahepatic biliary epithelial cells (IHBECs) can be transdifferentiated through the use of certain transcriptional factors into cells can express proteins characteristic of $\beta$-cells and secrete insulin $[201,239,257]$.

Lu et al. showed a new strategy to achieve the direct conversion of human hepatocytes into $\beta$ cells [222]. Hepatocytes were transfected with microRNA-302 (miR-302) mimic and Ngn3, Pdx1 and MafA expressed plasmids, followed by a chemical-defined culture system for maturation of the resulting insulin-secreting cells. Co-transfection of miR-302 mimic increased the transcription of pancreatic development-related genes including Foxa2, Sox17 and endogenous Pdx1. Furthermore, at the end of this treatment, hepatocytes became insulin expressed cells that released the hormone in response to a physiological glucose change in vitro. According to this previous study, the authors showed that miR-302 participation may facilitate the conversion of adult hepatocytes into pancreatic islets-like cells.

Nowadays, direct reprogramming of patientes own adult somatic cells into pancreatic $\beta$-cells skipping the stem cell induction phase is applied, therefore eliminating immune rejection and the risk of neoplastic formation. Previous studies indicated that the differentiated somatic cells proximal to the pancreatic $\beta$-cells might be an ideal starting material for pancreatic direct reprogramming [307-309]. However, most of transplanted pancreatic $\beta$-cells produced by direct reprogramming could not respond to ambient glucose change, because the reprogramming of input cell types is incomplete and the induced cells do not form natural islets structure. It is worth mentioning that the function units inside the pancreas are the islets of Langerhans where insulin producing cells, i.e. $\beta$-cells, are found in the core and surrounded by glucagon-, somatostatin-, ghrelin-producing and pancreatic polypeptide-, cells. The glucose homeostasis and level of insulin secretion are regulated by various cell types in a cooperative manner. Therefore, further works are required to consider reprogramming of all of the cell types inside the islet, at least the $\beta$ cells and $\alpha$ cells. In particular, the reprogrammed cells need to be organized into a normal structure prior to clinical application [309]

In addition to hepatocytes, other adult somatic cells, including pancreas ductal cells [310], endocrine $\alpha$ cells [309,311] and gall bladder cells [311,312], have been successfully transformed by direct reprogramming into insulin producing cells (Table 2).

Table 2: Generating pancreatic $\beta$-like cells from hepatocytes and other adult somatic cell types by direct reprogramming strategy [309].

\begin{tabular}{|c|c|c|c|c|c|c|c|c|}
\hline \multicolumn{2}{|c|}{ Adult somatic cells } & \multirow{2}{*}{$\begin{array}{r}\text { Race } \\
\text { Humans }\end{array}$} & \multirow{2}{*}{$\begin{array}{c}\text { In vivo } \\
\text { or in } \\
\text { vitro }\end{array}$} & \multirow{2}{*}{$\begin{array}{c}\text { Factors } \\
\text { Pdx1, Ngn3 }\end{array}$} & \multirow{2}{*}{$\begin{array}{c}\begin{array}{c}\text { Transduction } \\
\text { methods }\end{array} \\
\text { nucleofection }\end{array}$} & \multirow{2}{*}{$\begin{array}{c}\text { Efficiency } \\
50 \% \text { transduction efficiency }\end{array}$} & \multirow{2}{*}{$\begin{array}{c}\text { GS } \\
\text { Yes, } \\
\text { partly }\end{array}$} & \multirow{2}{*}{$\begin{array}{c}\text { References } \\
{[313]}\end{array}$} \\
\hline & hepatocytes & & & & & & & \\
\hline & hepatocytes & Rodents & In vitro & $\begin{array}{c}\text { Pdx1 essential for initial pancreatic } \\
\text { specification and/or Neurogenin 3, } \\
\text { NeuroD, NKx6.1, Nkx6, Pax4, Pax6 } \\
\text { and Islet1 }\end{array}$ & adenoviral vectors & N/A & N/A & {$[221]$} \\
\hline & hepatocytes & Rodents & In vivo & Pdx1, Ngn3 and MafA & $\begin{array}{l}\text { hydrodynamic gene } \\
\text { delivery }\end{array}$ & & N/A & {$[314]$} \\
\hline & $\underset{\text { tissue }}{\text { human }}$ liver & Humans & In vitro & Exendin 4 and $\mathrm{Pdx} 1$ & recombinant adenovirus & $10 \%$ insulin positive cells & No & {$[315]$} \\
\hline Endocrine cells & alpha cells & Rodents & In vivo & Pancreatic duct ligation and alloxan & N/A & $\begin{array}{l}\sim 10 \% \text { of the normal } \beta \text {-cell } \\
\text { mass }\end{array}$ & No & {$[316,317,318]$} \\
\hline \multirow{3}{*}{ Exocrine cells } & acinar cells & Rodents & In vivo & Pdx1, Ngn3 and MafA & adenovirus induction & high, $>20 \%$ & Yes & {$[319,320]$} \\
\hline & acinar cells & Rodents & $\begin{array}{l}\text { In vivo and } \\
\text { in vitro }\end{array}$ & $\mathrm{TR} \alpha$ & adenovirus vector & $\begin{array}{l}70 \% \text { transduction efficiency; } \\
\sim 35 \% \text { c-peptide positive } \\
\text { reprogrammed cells }\end{array}$ & No & {$[321]$} \\
\hline & $\begin{array}{l}\text { duct epithelial } \\
\text { cells }\end{array}$ & Rodents & In vivo & $\begin{array}{l}\text { Ngn3, Myt1 and } \delta \text {-notch signaling } \\
\text { modulator }\end{array}$ & adenovirus & $\begin{array}{l}\sim 6 \% \text { of the estimated pancreatic } \\
\text { reprogramming path completed }\end{array}$ & $\mathrm{N} / \mathrm{A}$ & [310] \\
\hline \multirow{3}{*}{$\begin{array}{l}\text { Gall bladder } \\
\text { cells }\end{array}$} & $\begin{array}{c}\text { Primary } \\
\text { intrahepatic } \\
\text { biliary epithelial } \\
\text { cells }\end{array}$ & Rodents & In vitro & Pdx1; NeuroD; Pdx1/vp16 & recombinant adenovirus & $30-50 \%$ & No & {$[322]$} \\
\hline & $\begin{array}{l}\text { primary mouse } \\
\text { gall bladder } \\
\text { epithelial cells }\end{array}$ & Rodents & In vitro & $\begin{array}{c}\text { Ngn3, Pdx1, and MafA; addition of } \\
\text { retinoic acid and inhibition of } \\
\text { Notch signaling }\end{array}$ & $\begin{array}{l}\text { E1-deleted adenovirus } \\
\text { (serotype 5) }\end{array}$ & $50 \%$ & No & [311] \\
\hline & $\begin{array}{l}\text { gall bladder } \\
\text { epithelial cells }\end{array}$ & Rodents & In vitro & Hes $1, \operatorname{Pdx} 1$ & recombinant adenovirus & $\begin{array}{l}\sim 40 \%-50 \% \text { transduction efficiency; } \sim 0.1 \% \\
\text { insulin contents of normal islets }\end{array}$ & Yes & [323] \\
\hline
\end{tabular}

N/A: Non-applicable or non-available; GS: Glucose Sensitivity 


\section{Ethical Considerations and Constraints}

Despite the tremendous therapeutic promise of human embryonic stem cells (HESCs) research, the research has met with heated opposition because the harvesting of HESCs involves the destruction of the human embryo. The basis of most of the current ethical concerns with HESCs is dependent on the need to derive the cell type from developing blastocysts. Because the blastocyst could potentially develop into an embryo if it was transferred to a suitably prepared recipient, the argument can be made that the derivation of ES cells interrupts normal development, which might have produced a human life [107]. As the stem cells from the embryos are obtained by destroying the embryo in most cases, this leads to release of arguments and questions about the origin of life and ethical rights to destroy the embryo. Thus, it is always advisable to follow the set of rules that are laid by the governing bodies around the globe based on the sentiments and beliefs of people from that particular geographica location [324].

There is a dichotomy between the advocates of research on HESCs and the advocates of the dignity of the embryos. Advocates of research on HESCs claim that the act of abandoning the embryo and the act of using it for research have the same moral status [325]. Many who believe that human embryos have moral status are convinced that their use in HESCs research can be morally justified as long as embryos left over from fertility treatments are discarded [326].

Since most investigators engaged in HESCs research do not participate in the derivation of HESCs but instead use cell lines that researchers who performed the derivation have made available [327], this would not suffice to show that all or even most HESC research is impermissible.

The debate about stem cells is also a religious one. As Dajani explained in her editorial, discussions in Jordan concluded that stemcell research is permissible in Islam providing it is carried out to improve human health, since Muslim scholars consider life to start 40 120 days after conception [328]. Denominations of the Christian faith, including Roman Catholics and Orthodox Christians, believe that the embryo has a status of a human individual from conception and therefore any decisions/interventions not in favor of the embryo violates the right of the embryo to life [176,329]. Thus, the availability of any eventual embryonic stem cell therapies will pose a dilemma and constraints in many countries and the stem cell research may be unacceptable [330].

As induced pluripotent stem cells have the potential to develop into a human embryo in effect producing a clone of the donor, their use in research and therapy is opposed like ESCs. However, many nations are already prepared for this, having legislation in place that bans human cloning for various purposes, although there is no consensus around the world on these policies [329].

Deriving embryonic stem cells from already existing embryonic stem cell lines is a less controversial practice than deriving them from spare embryos left from in vitro fertilization procedures. Stem cells derived from embryos created for research by somatic cell nuclear transfer technique raise major ethical objections and constraints from certain parts of society, arguing from religious and other moral perspectives $[47,331]$.

Derivation of stem cells from placenta, amniotic fluid, blood as well as from adult tissues and their use in research and clinical applications would not be expected to raise the same objections [107].

\section{Conclusion and Future Prospects}

Scientific efforts have been done by many authors to produce insulin secreting cells from stem cells at the past decade, and the future years may come up with the solutions to use stem cells as a therapeutic agent to cure diabetes. Thus, a further development for methods of differentiation and selection of completely functional $\beta$-cells is required. Obtaining $\beta$-cells from different types of stem cells can be improved by managing and regulating several factors. Embryonic and adult stem cells were applied for therapy of type 1 and type 2 diabetes mellitus due to their ability to differentiate into glucose-sensitive insulin-producing cells and their ability to improve the tissue insulin sensitivity and glycemic state. Direct reprogramming of human's own somatic cells into pancreatic $\beta$-cells by different gene delivery methods skipping pluripotent stage to avoid immune rejection and the risk of neoplasia formation will be important in clinical application for treatment of diabetes mellitus type 1 and 2 in the near future. In another way, more research strategies are required to activate pancreatic stem cells in diabetic patients to promote $\beta$-cell formation as well as to develop suitable methods of isolation and ex vivo expansion of pancreatic stem cells for transplantation.

In the years to come, the hepatic production of insulin has the potential to become a viable source for beta-cell replacement; this elucidation is based on the embryological proximity of the liver and pancreas. This is possible not before addressing the practical hurdles associated with these cell lines, complete differentiation, culture conditions and islet structure formation. The use of genetically modified stem cells, that have been passaged in cultures and subcultures for long periods of time, could deliver cell lines with genetic mutations for which the quality control measures and screening procedures are yet to be developed. Overall, the enhancement of understanding of the genes involved in pancreatic differentiation, the control of insulin levels, and profitable transplantation of islet cells developed from stem cells and direct reprogrammed transdifferentiated adult cells to pancreatic $\beta$-cells, will lead to the improvement of the care of patients with diabetes mellitus type 1 and 2. Thus, the literatures in this review provide promising approaches for use of HSCs and direct reprogrammed adult cells transdifferentiated into pancreatic $\beta$-cells in the diabetes treatment and invites collaborations to achieve future hopes of stem cell applications in regenerative medicines and therapies of diabetes mellitus as well as diseases that result from specific cell loss or damage. 
Citation: Ahmed OM, Sayed HM. Stem Cell Therapies in Regenerative Medicine and Diabetes Mellitus: Advances, Constraints and Future Prospects. J Transplant Stem Cel Biol. 2016;3(1): 22.

ISSN: $2374-9326$

\section{References}

1. Kim EJ, Kim N, Cho SG (2013) The potential use of mesenchymal stem cells in hematopoietic stem cell transplantation. Exp Mol Med 45: e2.

2. Caplan AI (1991) Mesenchymal stem cells. J Orthop Res 9: 641-650.

3. Owen M (1988) Marrow stromal stem cells. J Cell Sci Suppl 10:63-76

4. Thomson JA, Itskovitz-Eldor J, Shapiro SS, Waknitz MA, Swiergiel JJ, et al. (1998) Embryonic stem cell lines derived from human blastocysts Science 282: 1145-1147.

5. Gearhart J (1998) New potential for human embryonic stem cells Science 282: 1061-1062.

6. Voltarelli JC, Couri CE, Rodrigues MC, Moraes DA, Stracieri AB, et al (2011) Stem cell therapies for type 1 diabetes mellitus. Indian J Exp Biol 49: 395-400.

7. Si Y, Zhao Y, Hao H, Liu J, Guo Y, et al. (2012) Infusion of mesenchymal stem cells ameliorates hyperglycemia in type 2 diabetic rats identification of a novel role in improving insulin sensitivity. Diabetes 61: 1616-1625.

8. Katuchova J, Harvanova D, Spakova T, Kalanin R, Farkas D, et al (2015) Mesenchymal stem cells in the treatment of type 1 diabetes mellitus. Endocr Pathol 26: 95-103.

9. Bluestone JA, Herold K, Eisenbarth G (2010) Genetics, pathogenesis and clinical interventions in type 1 diabetes. Nature 464: 1293-1300.

10. American Diabetes Association (2015) Standards of medical care in diabetes. Volume 38, Supplement 1.

11. International Diabetes Federation (2012) IDF Diabetes Atlas, $\left(5^{\text {th }}\right.$ edn) update, Brussels.

12. DeFronzo RA (1997) Pathogenesis of type 2 diabetes: metabolic and molecular implications for identifying diabetes genes. Diabetes Rev 5: 177- 269 .

13. Ashcroft FM, Rorsman P (2012) Diabetes mellitus and the $\beta$ cell: the last ten years. Cell 148: 1160-1171.

14. Atkinson MA, Eisenbarth GS (2001) Type I diabetes: new perspectives on disease pathogenesis and treatment. Lancet 358: 221-229.

15. Shapiro AM, Lakey JR, Ryan EA, Korbutt GS, Toth E, et al. (2000) Islet transplantation in seven patients with type 1 diabetes mellitus using a glucocorticoid-free immunosuppressive regimen. N Engl J Med 343: 230- 238

16. Pagliuca FW, Melton DA (2013) How to make a functional $\beta$ cell. Development 140: 2472-2483.

17. Migliorini A, Bader E, Lickert H (2014) Islet cell plasticity and regeneration. Mol Metab 3: 268-274.

18. Couri CE, Oliveira MC, Stracieri AB, Moraes DA, Pieroni F, et al (2009) C-peptide levels and insulin independence following autologous nonmyeloablative hematopoietic stem cell transplantation in newly diagnosed type 1 diabetes mellitus. JAMA 301: 1573-1579.

19. Zhao Y, Jiang Z, Zhao T, Ye M, Hu C, et al. (2012) Reversal of type diabetes via islet $\beta$ cell regeneration following immune modulation by cord blood-derived multipotent stem cells. BMC Med 10:3.

20. Regeneration Center of Thailand (2015) Stem cell therapy to treat type 2 diabetes mellitus.

21. Zhao Y, Jiang Z, Zhao T, Ye M, Hu C, et al. (2013) Targeting insulin resistance in type 2 diabetes via immune modulation of cord bloodderived multipotent stem cells (CB-SCs) in stem cell educator therapy: phase I/II clinical trial. BMC Med 11: 160 .

22. Singh B, Chowdhary M (2014) Stem cell: Pluripotent cell or reserve cell? Indian J Clin Anat Physiol 1: 34-40.
23. Lee EH, Hui JH (2006) The potential of stem cells in orthopaedic surgery J Bone Joint Surg Br 88: 841-853.

24. Niwa H, Miyazaki J, Smith AG (2000) Quantitative expression of Oct-3/4 defines differentiation, dedifferentiation or self-renewal of ES cells. Nat Genet 24:372-376.

25. Munsie M, Juttner C, Herbert K (2015) The Australian Stem Cell Handbook. The National Stem Cell Foundation of Australia. Caulfield, VIC, pp. 3163.

26. Sheth N (2009) Effect of varying oxygen levels on murine embryonic stem cell differentiation into endoderm cells. Faculty of Drexel University, Philadelphia, USA.

27. Gardner RL (2007) Stem cells and regenerative medicine: principles, prospects and problems. C R Biol 330: 465-473.

28. Edwards RG (2004) Stem cells today: A. Origin and potential of embryo stem cells. Reprod Biomed Online 8: 275-306.

29. Bajada S, Mazakova I, Richardson JB, Ashammakhi N (2008) Updates onstem cells and their applications in regenerative medicine. J Tissue Eng Regen Med 2: 169-183.

30. Pellegrini G, De Luca M (2010) Human embryonic stem cell-derived keratinocytes: how close to clinics? Cell Stem Cell 6: 8-9.

31. Reubinoff BE, Itsykson P, Turetsky T, Pera MF, Reinhartz E, et al. (2001) Neural progenitors from human embryonic stem cells. Nat Biotechnol 19 1134-1140.

32. Schuldiner M, Eiges R, Eden A, Yanuka O, Itskovitz-Eldor J, et al. (2001) Induced neuronal differentiation of human embryonic stem cells. Brain Res 913: 201-205.

33. Zhang SC, Wernig M, Duncan ID, Brustle O, Thomson JA (2001) In vitro differentiation of transplantable neural precursors from human embryonic stem cells. Nat Biotechnol 19: 1129-1133.

34. Adewumi O, Aflatoonian B, Ahrlund-Richter L, Amit M, et al. (2007) Characterization of human embryonic stem cell lines by the Internationa Stem Cell Initiative. Nat Biotechnology 25:803-816

35. Kaufman DS, Hanson ET, Lewis RL, Auerbach R, Thomson JA (2001) Hematopoietic colony-forming cells derived from human embryonic stem cells. Proc Natl Acad Sci U S A 98: 10716-10721.

36. Kehat I, Kenyagin-Karsenti D, Snir M, Segev H, Amit M, et al. (2001) Human embryonic stem cells can differentiate into myocytes with structural and functional properties of cardiomyocytes. J Clin Invest 108 : 407-414.

37. Levenberg S, Golub JS, Amit M, Itskovitz-Eldor J, Langer R (2002) Endothelial cells derived from human embryonic stem cells. Proc Nat Acad Sci U S A 99: 4391-4396.

38. Assady S, Maor G, Amit M, Itskovitz-Eldor J, Skorecki KL, et al. (2001) Insulin production by human embryonic stem cells. Diabetes 50: 1691-1697.

39. Soria B, Roche E, Berna G, Leon-Quinto T, Reig JA, et al. (2000) Insulin secreting cells derived from embryonic stem cells normalize glycemia in streptozotocin-induced diabetic mice. Diabetes 49:157-162.

40. Hendricks WA, Pak ES, Owensby JP, Menta KJ, Glazova M, et al. (2006) Predifferentiated embryonic stem cells prevent chronic pain behaviors and restore sensory function following spinal cord injury in mice. Mol Med 12 34-46.

41. Kofidis T, de Bruin JL, Hoyt G, Ho Y, Tanaka M, et al. (2005) Myocardia restoration with embryonic stem cell bio artificial tissue transplantation. J Heart Lung Transplant 24:737-744.

42. Duan Y, Catana A, Meng Y, Yamamoto N, He S, et al. (2007) Differentiation and enrichment of hepatocyte-like cells from human embryonic stem cells in vitro and in vivo. Stem Cells 25:3058-3068.

43. Guenou H, Nissan X, Larcher F, Feteira J, Lemaitre G, et al. (2009) Human embryonic stem-cell derivatives for full reconstruction of the 
pluristratified epidermis: a preclinical study. Lancet 374: 1745-1753.

44. Jukes JM, van Blitterswijk CA, Boer J (2010) Skeletal tissue engineering using embryonic stem cells. J Tissue Eng Regen Med 4: 165-180.

45. Yabut O, Bernstein HS (2011) The promise of human embryonic stem cells in aging-associated diseases. Aging (Albany NY) 3: 494-508

46. Rockville MD (1999) Ethical issues. In: Human stem cell research, Human Stem Cell Research and the Potential for Clinical Application, pp. $1,8-12$.

47. Hug K (2005) Sources of human embryos for stem cell research: ethica problems and their possible solutions. Medicina (Kaunas) 41: 1002-1010.

48. Gurdon JB, Melton DA (2008) Nuclear reprogramming in cells. Science 322: 1811-1815.

49. National Institutes of Health (2001) Stem cells: Scientific progress and future research directions. Department of Health and Human Services, Stem Cell Information, Bethesda.

50. Nichols J, Smith A (2011) The origin and identity of embryonic stem cells. Development 138:3-8.

51. Kawaharada K, Kawamata M, Ochiya T (2015) Rat embryonic stem cells create new era in development of genetically manipulated rat models. World J Stem Cells 7: 1054-1063.

52. Bongso A, Fong CY, Ng SC, Ratnam S (1994) Isolation and culture of inner cell mass cells from human blastocysts. Hum Reprod 9: 2110-2117.

53. Reubinoff BE, Pera MF, Fong CY, Trounson A, Bongso A (2000) Embryonic stem cell lines from human blastocysts: somatic differentiation in vitro. Nat Biotechnol 18: 399-404.

54. Bongso A (1999) Handbook on blastocyst culture. Sydney Press Indus print, Singapore.

55. Bongso A (1996) Behaviour of human embryos in vitro in the first 14 days: blastocyst transfer and embryonic stem cell production. Clin Sci (Lond) 91: 248-249.

56. Fong CY, Bongso A, Ng SC, Kumar J, Trounson A, et al. (1998) Blastocyst transfer after enzymatic treatment of the zona pellucida: improving in-vitro fertilization and understanding implantation. Hum Reprod 13: 2926-2932.

57. Kiessling AA (2010) Timing is everything in the human embryo. Nat Biotechnol 28: 1025-1026.

58. Bongso A, Fong CY, Mathew J, Ng LC, Kumar J, et al. (1999) The benefits to human IVF by transferring embryos after the in vitro embryonic block: alternatives to day-2 transfers. Asstd Reprod Revs 1: $70-78$

59. Bongso TA, Fong CY, Ng CY, Ratnam SS (1994) Blastocyst transfer in human in vitro fertilization: the use of embryo co-culture. Cell Biol Int 18: 1181-1189.

60. Gardner DK, Schoolcraft WB (1999) Culture and transfer of human blastocysts. Curr Opin Obstet Gynecol 11:307-311.

61. Sathananthan AH (1997) Ultrastructure of the human egg. Hum Cell 10 21-38.

62. De Vos A, Van Steirteghem A (2000) Zona hardening, zona drilling and assisted hatching: new achievements in assisted reproduction. Cells Tissues Organs 166:220-227.

63. Trounson A, Anderiesz C, Jones G (2001) Maturation of human oocytes in vitro and their developmental competence. Reproduction 121:51-75.

64. National Institutes of Health (2009) The human embryonic stem cell and the human embryonic germ cell. In: Stem Cell Information, U.S. Department of Health and Human Services, Bethesda.

65. Lumelsky N, Blondel O, Laeng P, Velasco I, Ravin R, et al. (2001) Differentiation of embryonic stem cells to insulin-secreting structures similar to pancreatic islets. Science 292: 1389-1394.

66. Risau W, Sariola H, Zerwes HG, Sasse J, Ekblom P, et al. (1988) Vasculogenesis and angiogenesis in embryonic-stem-cell-derived embryoid bodies. Development 102:471-478.

67. Yamashita J, Itoh H, Hirashima M, Ogawa M, Nishikawa S, et al. (2000) Flk1-positive cells derived from embryonic stem cells serve as vascular progenitors. Nature 408:92-96.

68. Nakamura Y (2011) ES cell-derived erythroid cell lines able to produce mature red blood cells. In: Atwood C (Ed) Embryonic stem cells-recent advances in pluripotent stem cell-based regenerative medicine. pp. 291-302.

69. Fairchild PJ, Brook FA, Gardner RL, Graca L, Strong V, et al. (2000) Directed differentiation of dendritic cells from mouse embryonic stem cells. Curr Biol 10: 1515-1518.

70. Dani C, Smith AG, Dessolin S, Leroy P, Staccini L, et al. (1997) Differentiation of embryonic stem cells into adipocytes in vitro. J Cell Sci 110: 1279-1285.

71. Fraichard A, Chassande O, Bilbaut G, Dehay C, Savatier P, et al. (1995) In vitro differentiation of embryonic stem cells into glial cells and functional neurons. J Cell Sci 108:3181-3188.

72. Doetschman TC, Eistetter H, Katz M, Schmit W, Kemler R (1985) The in vitro development of blastocyst derived embryonic stem cell lines: formation of visceral yolk sac, blood islands and myocardium. J Embryol Exp Morph 87: 27-45

73. Maltsev VA, Rohwedel J, Hescheler J, Wobus AM (1993) Embryonic stem cells differentiate in vitro into cardiomyocytes representing sinusnodal, atrial and ventricular cell types. Mech Dev 44:41-50.

74. Kramer J, Hegert C, Guan K, Wobus AM, Muller PK, et al. (2000) Embryonic stem cell-derived chondrogenic differentiation in vitro: activation by BMP-2 and BMP-4. Mech Dev 92: 193-205.

75. Nakano T, Kodama H, Honjo T (1996) In vitro development of primitive and definitive erythrocytes from different precursors. Science 272: 722 724.

76. Nishikawa SI, Nishikawa S, Hirashima M, Matsuyoshi N, Kodama H (1998) Progressive lineage analysis by cell sorting and culture identifies FLK1+VE- cadherin+ cells at a diverging point of endothelial and hemopoieticlineages. Development 125:1747-1757.

77. Wiles MV, Keller G (1991) Multiple hematopoietic lineages develop from embryonic stem (ES) cells in culture. Development 111:259-267.

78. Bagutti C, Wobus AM, Fassler R, Watt FM (1996) Differentiation of embryonal stem cells into keratinocytes: comparison of wild-type and beta 1 integrin-deficient cells. Dev Biol 179: 184-196.

79. Potocnik AJ, Nielsen PJ, Eichmann K (1994) In vitro generation of lymphoid precursors from embryonic stem cells. EMBO J 13: 5274-5283.

80. Tsai M, Wedemeyer J, Ganiatsas S, Tam SY, Zon LI, et al. (2000) In vivo immunological function of mast cells derived from embryonic stem cells: an approach for the rapid analysis of even embryonic lethal mutations in adult mice in vivo. Proc Natl Acad Sci U S A 97:9186-9190.

81. Brustle O, Jones KN, Learish RD, Karram K, Choudhary K, et al. (1999) Embryonic stem cell-derived glial precursors: a source of myelinating transplants. Science 285: 754-756.

82. Liu S, Qu Y, Stewart TJ, Howard MJ, Chakrabortty S, et al. (2000) Embryonic stem cells differentiate into oligodendrocytes and myelinate in culture and after spinal cord transplantation. Proc Natl Acad Sci U S A 97: 6126-6131.

83. Buttery LD, Bourne S, Xynos JD, Wood H, Hughes FJ, et al. (2001) Differentiation of osteoblasts and in vitro bone formation from murine embryonic stem cells. Tissue Eng 7: 89-99.

84. Rohwedel J, Maltsev V, Bober E, Arnold HH, Hescheler J, et al. (1994) Muscle cell differentiation of embryonic stem cells reflects myogenesis in 
vivo: developmentally regulated expression of myogenic determination genes and functional expression of ionic currents. Dev Biol 164: 87-101.

85. Bain G, Kitchens D, Yao M, Huettner JE, Gottlieb DI (1995) Embryonic stem cells express neuronal properties in vitro. Dev Biol 168: 342-357.

86. Strubing C, Ahnert-Hilger G, Shan J, Wiedenmann B, Hescheler J, et al (1995) Differentiation of pluripotent embryonic stem cells into the neuronal lineage in vitro gives rise to mature inhibitory and excitatory neurons. Mech Dev 53:275-287.

87. Wei W, Lu Y, Hao B, Zhang K, Wang Q, et al. (2015) CD38 is required for neural differentiation of mouse embryonic stem cells by modulating reactive oxygen species. Stem Cells 33:2664-2673.

88. Noguchi TK, Ninomiya N, Sekine M, Komazaki S, Wang PC, et al (2015) Generation of stomach tissue from mouse embryonic stem cells. Nat Cell Biol 17: 984-993.

89. Donovan PJ (1998) The germ cell--the mother of all stem cells. Int J Dev Biol 42: 1043-1050.

90. Donovan PJ (1994) Growth factor regulation of mouse primordial germ cell development. Curr Top Dev Biol 29: 189-225.

91. Matsui Y (1998) Developmental fates of the mouse germ cell line. Int J Dev Biol 42: 1037-1042.

92. Surani MA (2001) Reprogramming of genome function through epigenetic inheritance. Nature 414:122-128.

93. Shamblott MJ, Axelman J, Wang S, Bugg EM, Littlefield JW, et al (1998) Derivation of pluripotent stem cells from cultured human primordial germ cells. Proc Natl Acad Sci U S A 95: 13726-13731.

94. Amit M, Carpenter MK, Inokuma MS, Chiu CP, Harris CP, et al. (2000) Clonally derived human embryonic stem cell lines maintain pluripotency and proliferative potential for prolonged periods of culture. Dev Bio 227: $271-278$

95. Shamblott MJ, Axelman J, Littlefield JW, Blumenthal PD, Huggins GR, et al. (2001) Human embryonic germ cell derivatives express a broad range of developmentally distinct markers and proliferate extensively in vitro. Proc Natl Acad Sci U S A 98:113-118.

96. Odorico JS, Kaufman DS, Thomson JA (2001) Multilineage differentiation from human embryonic stem cell lines. Stem Cells 19: 193-204.

97. Itskovitz-Eldor J, Schuldiner M, Karsenti D, Eden A, Yanuka O, et al. (2000) Differentiation of human embryonic stem cells into embryoid bodies comprising the three embryonic germ layers. Mol Med 6: 88-95.

98. Schuldiner M, Yanuka O, Itskovitz-Eldor J, Melton DA, Benvenisty N (2000) Effects of eight growth factors on the differentiation of cells derived from human embryonic stem cells. Proc Natl Acad Sci U S A 97: 11307-11312.

99. Cai J, Zhao Y, Liu Y, Ye F, Song Z, et al. (2007) Directed differentiation of human embryonic stem cells into functional hepatic cells. Hepatology 45: $1229-1239$

100. Touboul T, Hannan NR, Corbineau S, Martinez A, Martinet C, et al (2010) Generation of functional hepatocytes from human embryonic stem cells under chemically defined conditions that recapitulate liver development. Hepatology 51:1754-1765.

101. Huang SX, Islam MN, ONeill J, Hu Z, Yang YG, et al. (2014) Efficient generation of lung and airway epithelial cells from human pluripotent stem cells. Nat Biotechnol 32: 84-91.

102. Tamagawa T, Ishiwata I, Saito S (2004) Establishment and characterization of a pluripotent stem cell line derived from human amniotic membranes and initiation of germ layers in vitro. Hum Cell 17: 125-130.

103. Miki T, Lehmann T, Cai H, Stolz DB, Strom SC (2005) Stem cell characteristics of amniotic epithelial cells. Stem Cells 23: 1549-1559.

104. De Coppi P, Bartsch G Jr, Siddiqui MM, Xu T, Santos CC, et al. (2007) Isolation of amniotic stem cell lines with potential for therapy. Nat Biotechnol 25: 100-106.

105. Hmadcha A, Dominguez-Bendala J, Wakeman J, Arredouani M, Soria B (2009) The immune boundaries for stem cell based therapies: problems and prospective solutions. J Cell Mol Med 13:1464-1475.

106. Zare S, Kurd S, Rostamzadeh A, Nilforoushzadeh MA (2014) Types of stem cells in regenerative medicine: a review. J Skin Stem Cell 1: e28471.

107. Miki T, Strom SC (2006) Amnion-derived pluripotent/multipotent stem cells. Stem Cell Rev 2: 133-142.

108. Barker JN, Wagner JE (2003) Umbilical cord blood transplantation: current practice and future innovations. Crit Rev Oncol Hematol 48: 35-43.

109. Koh LP, Chao NJ (2004) Umbilical cord blood transplantation in adults using myeloablative and nonmyeloablative preparative regimens. Biol Blood Marrow Transplant 10: 1-22.

110. Wagner JE, Barker J (2004) Umbilical cord blood transplantation: nove approaches toward improving engraftment. Biol Blood Marrow Transplant 10: 733 .

111. Harris DT, Badowski M, Ahmad N, Gaballa A (2007) The potential of cord blood stem cells for use in regenerative medicine. Expert Opin Biol Ther 7: 1311-1322.

112. Hmadcha A, Domínguez-Bendala J, Wakeman J, Arredouani M, Soria B (2009) The immune boundaries for stem cell based therapies: problems and prospective solutions. J Cell Mol Med 13:1464-1475.

113. McGuckin CP, Forraz N, Baradez MO, Navran S, Zhao J, et al. (2005) Production of stem cells with embryonic characteristics from human umbilical cord blood. Cell Prolif 38:245-255.

114. Taylor A, Verhagen J, Blaser K, Akdis M, Akdis CA (2006) Mechanisms of immune suppression by interleukin-10 and transforming growth factorbeta: the role of T regulatory cells. Immunology 117: 433-442.

115. Hollands P (2009) Cord blood stem cells-the basic science. In: Bhattacharya N, Stubblefield P (Eds). Frontiers of cord blood science. Springer, London, pp. 19-25.

116. Arno A, Smith AH, Blit PH, Shehab MA, Gauglitz GG, et al. (2011) Stem cell therapy: a new treatment for burns? Pharmaceuticals (Basel) 4: 1355 1380 .

117. Leblond CP (1964) Classification of cell populations on the basis of their proliferative behavior. Natl Cancer Inst Monogr 14: 119-150

118. Holtzer H (1978) Cell lineages, stem cells and the ,quantal ${ }^{\text {ee }}$ cell cycle concept. In: Lord BI, Potten CS, Cole RJ (Eds). Stem cells and tissue homeostasis. Cambridge University Press, Cambridge, New York, pp. 1-28.

119. Ramakrishna V, Janardhan PB, Sudarsanareddy L (2011) Stem cells and regenerative medicine. a review. Annu Rev Res Biol 1:79-110.

120. Eckfeldt CE, Mendenhall EM, Verfaillie CM (2005) The molecular repertoire of the ,almighty ${ }^{e e}$ stem cell. Nat Rev Mol Cell Biol 6: 726-737.

121. Jones R, Lebkowski J, McNiece I (2010) Stem cells. Biol Blood Marrow Transplant 16(1 Suppl): S115-S118.

122. Fishbach GD, Fischbach RL (2004) Stem cells: science, policy, and ethics $\mathrm{J}$ Clin Invest 114: 1364-1370.

123. Tomar GB, Srivastava RK, Gupta N, Barhanpurkar AP, Pote ST, et al (2010) Human gingival-derived mesenchymal stem cells are superior to bone marrow-derived mesenchymal stem cells for cell therapy in regenerative medicine. Biochem Biophys Res Commun 393: 377-383.

124. Abo Elkheir W, Reda MA, Montaser IA, Salem AE, Sakr MA (2015) Intratheca autologous bone marrow derived mesenchymal stem cells for ischemic stroke: short term safety and efficacy study. Am J Biosci Bioeng 3: 1-6 
125. Pittenger MF, Martin BJ (2004) Mesenchymal stem cells and their potential as cardiac therapeutics. Circ Res 95: 9-20.

126. Chen Y, Shao JZ, Xiang LX, Dong XJ, Zhang GR (2008) Mesenchyma stem cells: a promising candidate in regenerative medicine. Int J Biochem Cell Biol 40: 815-820.

127. Dennis JE, Caplan AI (2004) Bone marrow mesenchymal stem cells. In Sell S (Ed) Stem cells handbook. Humana Press, Totowa, pp. 107-118.

128. Zvaifler NJ, Marinova-Mutafchieva L, Adams G, Edwards CJ, Moss J, et al. (2000) Mesenchymal precursor cells in the blood of normal individuals. Arthritis Res 2: 477-488.

129. De Bari C, Dell'^Accio F, Tylzanowski P, Luyten FP (2001) Multipotent mesenchymal stem cells from adult human synovial membrane. Arthritis Rheum 44: 1928-1942.

130. Nöth U, Osyczka AM, Tuli R, Hickok NJ, Danielson KG, et al. (2002) Multilineage mesenchymal differentiation potential of human trabecular bone-derived cells. J Orthop Res 20: 1060-1069.

131. Zuk PA, Zhu M, Mizuno H, Huang J, Futrell JW, et al. (2001) Multilineage cells from human adipose tissue: implications for cell-based therapies. Tissue Eng 7:211-228.

132. Pierdomenico L, Bonsi L, Calvitti M, Rondelli D, Arpinati M, et al. (2005) Multipotent mesenchymal stem cells with immunosuppressive activity can be easily isolated from dental pulp. Transplantation 80: 836842 .

133. Young HE, Steele TA, Bray RA, Hudson J, Floyd JA, et al. (2001) Human reserve pluripotent mesenchymal stem cells are present in the connective tissues of skeletal muscle and dermis derived from fetal, adult, and geriatric donors. Anat Rec 264: 51-62.

134. Sabatini F, Petecchia L, Tavian M, Jodon de Villeroché V, Rossi GA, et al. (2005) Human bronchial fibroblasts exhibit a mesenchymal stem cell phenotype and multilineage differentiating potentialities. Lab Invest 85 962- 971

135. Verfaillie CM (2002) Hematopoietic stem cells for transplantation. Nat Immunol 3: 314-317.

136. Orkin SH, Morrison SJ (2002) Stem-cell competition. Nature 418: 25-27.

137. National Institutes of Health (2001) The adult stem cells. In: Stem cells: scientific progress and future research directions, pp. 23-42.

138. Gage FH (2000) Mammalian neural stem cells. Science 287: 1433-1438.

139. Baizabal JM, Furlan-Magaril M, Santa-Olalla J, Covarrubias L (2003) Neural stem cells in development and regenerative medicine. Arch Med Res 34: 572-588.

140. Brignier AC, Gewirtz AM (2010) Embryonic and adult stem cell therapy. J Allergy Clin Immunol 125(2 Suppl 2): S336-S344.

141. Clarke DL, Johansson CB, Wilbertz J, Veress B, Nilsson E, et al. (2000) Generalized potential of adult neural stem cells. Science 288: 1660-1663.

142. Bjornson CR, Rietze RL, Reynolds BA, Magli MC, Vescovi AL (1999) Turning brain into blood: a hematopoietic fate adopted by adult neural stem cells in vivo. Science 283: 534-537.

143. Galli R, Borello U, Gritti A, Minasi MG, Bjornson C, et al. (2000) Skeletal myogenic potential of human and mouse neural stem cells. Nat Neurosci 3:986-991.

144. Seaberg RM, Smukler SR, Kieffer TJ, Enikolopov G, Asghar Z, et al. (2004) Clonal identification of multipotent precursors from adult mouse pancreas that generate neural and pancreatic lineages. Nat Biotechnol 22: $1115-1124$

145. Bouwens L, Rooman I (2005) Regulation of pancreatic beta-cell mass Physiol Rev 85: 1255-1270.

146. Suen PM, Leung PS (2005) Pancreatic stem cells: a glimmer of hope for diabetes? JOP 6: 422-424.

147. Ma M, Sha J, Zhou Z, Zhou Q, Li Q (2008) Generation of patientspecific pluripotent stem cells and directed differentiation of embryonic stem cells for regenerative medicine. Journal of Nanjing Medical University 22: 135-142.

148. Bouwens L, Houbracken I, Mfopou JK (2013) The use of stem cells for pancreatic regeneration in diabetes mellitus. Nat Rev Endocrinol 9: 598 606.

149. Watt FM (2002) Role of integrins in regulating epidermal adhesion, growth and differentiation. EMBO J 21: 3919-3926.

150. Blanpain C, Lowry WE, Geoghegan A, Polak L, Fuchs E (2004) Selfrenewal, multipotency, and the existence of two cell populations within an epithelial stem cell niche. Cell 118: 635-648.

151. Morris RJ, Liu Y, Marles L, Yang Z, Trempus C, et al. (2004) Capturing and profiling adult hair follicle stem cells. Nat Biotechnol 22: 411-417.

152. Li L, Xie T (2005) Stem cell niche: structure and function. Annu Rev Cell Dev Biol 21:605-631.

153. Rendl M, Lewis L, Fuchs E (2005) Molecular dissection of mesenchymal- epithelial interactions in the hair follicle. PLoS Biol 3 : e331.

154. Millar SE (2005) An ideal society? Neighbors of diverse origins interact to create and maintain complex mini-organs in the skin. PLoS Biol 3 e372.4

155. Levy V, Lindon C, Harfe BD, Morgan BA (2005) Distinct stem cel populations regenerate the follicle and interfollicular epidermis. Dev Cell 9: 855-861.

156. Flores I, Cayuela ML, Blasco MA (2005) Effects of telomerase and telomere length on epidermal stem cell behavior. Science 309: 1253-1256.

157. Sarin KY, Cheung P, Gilison D, Lee E, Tennen RI, et al. (2005) Conditional telomerase induction causes proliferation of hair follicle stem cells. Nature 436: 1048-1052.

158. Sieber-Blum M, Grim M (2004) The adult hair follicle: cradle for pluripotent neural crest stem cells. Birth Defects Res C Embryo Today 72:162-172

159. Fang D, Nguyen TK, Leishear K, Finko R, Kulp AN, et al. (2005) A tumorigenic subpopulation with stem cell properties in melanomas. Cancer Res 65:9328-9337.

160. Kuang S, Kuroda K, Le Grand F, Rudnicki MA (2007) Asymmetric selfrenewal and commitment of satellite stem cells in muscle. Cell 129: 999 1010 .

161. Zuk PA, Zhu M, Ashjian P, De Ugarte DA, Huang JI, et al. (2002) Human adipose tissue is a source of multipotent stem cells. Mol Biol Cell 13: 4279- 4295 .

162. Halvorsen YD, Franklin D, Bond AL, Hitt DC, Auchter C, et al. (2001) Extracellular matrix mineralization and osteoblast gene expression by human adipose tissue-derived stromal cells. Tissue Eng 7: 729-741.

163. Erickson GR, Gimble JM, Franklin DM, Rice HE, Awad H, et al. (2002) Chondrogenic potential of adipose tissue-derived stromal cells in vitro and in vivo. Biochem Biophys Res Commun 290: 763-769.

164. Huang JI, Zuk PA, Jones NF, Zhu M, Lorenz HP, et al. (2004) Chondrogenic potential of multipotential cells from human adipose tissue. Plast Reconstr Surg 113: 585-594.

165. Safford KM, Hicok KC, Safford SD, Halvorsen YD, Wilkison WO, et al (2002) Neurogenic differentiation of murine and human adipose-derived stromal cells. Biochem Biophys Res Commun 294: 371-379.

166. Ashjian PH, Elbarbary AS, Edmonds B, DeUgarte D, Zhu M, et al (2003) In vitro differentiation of human processed lipoaspirate cells into early neural progenitors. Plast Reconstr Surg 111: 1922-1931. 
167. Mizuno H, Zuk PA, Zhu M, Lorenz HP, Benhaim P, et al. (2002) Myogenic differentiation by human processed lipoaspirate cells. Plast Reconstr Surg 109: 199-209.

168. Rangappa S, Fen C, Lee EH, Bongso A, Sim EK (2003) Transformation of adult mesenchymal stem cells isolated from the fatty tissue into cardiomyocytes. Ann Thorac Surg 75: 775-779.

169. Cousin B, Andre M, Arnaud E, Penicaud L, Casteilla L (2003) Reconstitution of lethally irradiated mice by cells isolated from adipose tissue. Biochem Biophys Res Commun 301: 1016-1022.

170. Charrière G, Cousin B, Arnaud E, André M, Bacou F, et al. (2003) Preadipocyte conversion to macrophage. Evidence of plasticity. J Biol Chem 278: 9850-9855.

171. Ruhnke M, Ungefroren H, Nussler A, Martin F, Brulport M, et al. (2005) Differentiation of in vitro-modified human peripheral blood monocytes into hepatocyte-like and pancreatic islet-like cells. Gastroenterology 128: 1774- 1786.

172. Leri A, Kajstura J, Anversa P (2005) Cardiac stem cells and mechanisms of myocardial regeneration. Physiol Rev 85: 1373-1416.

173. Lyngbæk S, Schneider M, Hansen JL, Sheikh SP (2007) Cardiac regeneration by resident stem and progenitor cells in the adult heart. Basic Res Cardiol 102: 101-114.

174. Rubart M, Field LJ (2006) Cardiac regeneration: repopulating the heart. Ann Rev Physiol 68: 29-49.

175. Bilic J, Izpisua Belmonte JC (2012) Concise review: Induced pluripotent stem cells versus embryonic stem cells: close enough or yet too far apart? Stem Cells 30: 33-41.

176. Euro Stem Cell (2015) Origins, ethics and embryos: the sources of human embryonic stem cells.

177. Singh VK, Kalsan M, Kumar N, Saini A, Chandra R (2015) Induced pluripotent stem cells: applications in regenerative medicine, disease modeling, and drug discovery. Front Cell Dev Biol 3: 1 .

178. Takahashi K, Yamanaka S (2006) Induction of pluripotent stem cells from mouse embryonic and adult fibroblast cultures by defined factors. Cell 126: 663-676.

179. Takahashi K, Tanabe K, Ohnuki M, Narita M, Ichisaka T, et al. (2007) Induction of pluripotent stem cells from adult human fibroblasts by defined factors. Cell 131: 861-872.

180. Yu J, Vodyanik MA, Smuga-Otto K, Antosiewicz-Bourget J, Frane JL, et al. (2007) Induced pluripotent stem cell lines derived from human somatic cells. Science 318: 1917-1920.

181. Maheralim N, Sridharan R, Xie W, Utikal J, Eminli S, et al. (2007) Directly reprogrammed fibroblasts show global epigenetic remodeling andwidespread tissue contribution. Cell Stem Cell 1: 55-70.

182. Liu H, Zhu F, Yong J, Zhang P, Hou P, et al. (2008) Generation of induced pluripotent stem cells from adult rhesus monkey fibroblasts. Cell Stem Cell 3: 587-590.

183. Liao J, Cui C, Chen S, Ren J, Chen J, et al. (2009) Generation of induced pluripotent stem cell lines from adult rat cells. Cell Stem Cell 4: 11-15.

184. Li W, Wei W, Zhu S, Zhu J, Shi Y, et al. (2009) Generation of rat and human induced pluripotent stem cells by combining genetic reprogramming and chemical inhibitors. Cell Stem Cell 4: 16-19.

185. Weissman IL (2000) Stem cells: Uunits of development, units of regeneration, and units in evolution. Cell 100: 157-168.

186. Melton DA (2006) Stemness: Definitions, criteria, and standards. In: Lanza R, Atala A (Eds). Essentials of stem cell biology, (3rdedn). Elsevier/Academic Press, USA, pp. 7-18.

187. Sidhu KS, Ryan JP, Lees JG, Tuch BE (2010) Derivation of a new human embryonic stem cell line, endeavour-2, and its characterization. In vitro Cell Develop Biol Anim 46: 269-275.
188. Bajada S, Mazakova I, Richardson JB, Ashammakhi N (2008) Updates on stem cells and their applications in regenerative medicine. J Tissue Eng Regen Med 2: 169-183.

189. Atala A (2014) Human stem cell-derived retinal cells for macular diseases. Lancet 385: 487-488.

190. Ben-Hur T, Idelson M, Khaner H, Pera M, Reinhartz E, et al. (2004) Transplantation of human embryonic stem cell-derived neural progenitors improves behavioural deficit in Parkinsonian rats. Stem Cells 22: 12461255 .

191. Kofidis T, Lebl DR, Swijnenburg RJ, Greeve JM, Klima U, et al. (2006) Allopurinol/uricase and ibuprofen enhance engraftment of cardiomyocyte- enriched human embryonic stem cells and improve cardiac function following myocardial injury. Eur J Cardiothorac Surg 29: $50-55$.

192. Singh P, Williams DJ (2008) Cell therapies: realizing the potential of this new dimension to medical therapeutics. J Tissue Eng Regen Med 2: 307 319.

193. Serra V, von Zglinicki T (2002) Human fibroblasts in vitro senesce with a donor-specific telomere length. FEBS Lett 516: 71-74.

194. Frenck RW Jr, Blackburn EH, Shannon KM (1998) The rate of telomere sequence loss in human leukocytes varies with age. Proc Natl Acad Sci U S A 95: 5607-5610.

195. Rufer N, Brümmendorf TH, Kolvraa S, Bischoff C, Christensen K, et al. (1999) Telomere fluorescence measurements in granulocytes and $\mathrm{T}$ lymphocyte subsets point to a high turnover of hematopoietic stem cells and memory T cells in early childhood. J Exp Med 190: 157-167.

196. Reyes M, Lund T, Lenvik T, Aguiar D, Koodie L, et al. (2001) Purification and ex vivo expansion of postnatal human marrow mesodermal progenitor` cells. Blood 98: 2615-2625.

197. Lo B, Parham L (2009) Ethical issues in stem cell research. Endocr Rev 30: 204-213.

198. The Guardian (2014) Stem cell therapy success in treatment of sight loss from macular degeneration.

199. Schwartz SD, Regillo CD, Lam BL, Eliott D, Rosenfeld PJ, et al. (2015) Human embryonic stem cell-derived retinal pigment epithelium in patients with age-related macular degeneration and Stargardt"s macular dystrophy: follow-up of two open-label phase $1 / 2$ studies. Lancet 385 : 509-516.

200. Mimeault M, Batra SK (2008) Recent progress on tissue-resident adult stem cell biology and their therapeutic implications. Stem Cell Rev 4: $27-$ 49.

201. $\mathrm{Xi} \mathrm{Y}, \mathrm{Bu} \mathrm{S}$ (2014) Stem cells therapy in diabetes mellitus. J Stem Cell Res Ther 4: 1-6.

202. Alison MR, Islam S (2009) Attributes of adult stem cells. J Pathol 217 144- 160 .

203. Bonnet D (2003) Biology of human bone marrow stem cells. Clin Exp Med 3: 140-149.

204. Armitage JO (1994) Bone marrow transplantation. N Engl J Med 330 827- 838 .

205. Copelan EA (2006) Hematopoietic stem-cell transplantation. N Engl J Med 354: 1813-1826.

206. Raff M (2003) Adult stem cell plasticity: Fact or artifact? Annu Rev Cell Dev Biol 19: 1-22.

207. Lensch MW (2009) Cellular reprogramming and pluripotency induction Br Med Bull 90: 19-35

208. Hirschi KK, Li S, Roy K (2014) Induced pluripotent stem cells for regenerative medicine. Annu Rev Biomed Eng 16: 277-294.

209. Reardon S, Cyranoski D (2014) Japan stem-cell trial stirs envy. Nature 


\section{3: $287-288$.}

210. Liu H, Kim Y, Sharkis S, Marchionni L, Jang YY (2011) In vivo liver regeneration potential of human induced pluripotent stem cells from diverse origins. Sci Transl Med 3: 82ra39.

211. Nori S, Okada Y, Yasuda A, Tsuji O, Takahashi Y, et al. (2011) Grafted human-induced pluripotent stem-cell-derived neurospheres promote motor functional recovery after spinal cord injury in mice. Proc Natl Acad Sci U S A 108: 16825-16830.

212. Tan Q, Lui PP, Rui YF, Wong YM (2012) Comparison of potentials of stem cells isolated from tendon and bone marrow for musculoskeletal tissue engineering. Tissue Eng Part A 18: 840-851.

213. Suzuki N, Yamazaki S, Yamaguchi T, Okabe M, Masaki H, et al. (2013) Generation of engraftable hematopoietic stem cells from induced pluripotent stem cells by way of teratoma formation. Mol Ther 21: 14241431

214. Lim WF, Inoue-Yokoo T, Tan KS, Lai MI, Sugiyama D (2013) Hematopoietic cell differentiation from embryonic and induced pluripotent stem cells. Stem Cell Res Ther 4: 71

215. Cao F, Wagner RA, Wilson KD, Xie X, Fu JD, et al. (2008) Transcriptional and functional profiling of human embryonic stem cellderived cardiomyocytes. PLoS ONE 3: e3474

216. Levenberg S, Ferreira LS, Chen-Konak L, Kraehenbuehl TP, Langer R (2010) Isolation, differentiation and characterization of vascular cells derived from human embryonic stem cells. Nat Protoc 5: 1115-1126.

217. Sena CM, Bento CF, Pereira P, Seica R (2010) Diabetes mellitus: new challenges and innovative therapies. EPMA J 1: 138-163.

218. American Diabetes Association (2006) Pancreas and islet transplantation in type 1 diabetes. Diabetes Care 29: 935.

219. National Institutes of Health (2015) Stem cells and diabetes. In: Stem cell information. Department of Health and Human Services, Stem Cell Information, Bethesda.

220. Yanai G, Hayashi T, Zhi Q, Yang KC, Shirouzu Y, et al. (2013) Electrofusion of mesenchymal stem cells and islet cells for diabetes therapy: a rat model. PLoS One 8: e64499.

221. Thowfeequ S, Li WC, Slack JM, Tosh D (2009) Reprogramming of liver to pancreas. In: Audet J, William L (Eds). Stem Cells in Regenerative Medicine, (482nd edn). Humana Press, pp. 407-418.

222. Lu J, Dong H, Lin L, Wang Q, Huang L, et al. (2014) miRNA-302 facilitates reprogramming of human adult hepatocytes into pancreatic islets-like cells in combination with a chemical defined media. Biochem Biophys Res Commun 453: 405-410.

223. Trounson A (2013) A rapidly evolving revolution in stem cell biology and medicine. Reprod Biomed 27: 756-764

224. National Institutes of Health (2001) Stem cells and diabetes. In: Stem cells: scientific progress and future research directions, pp. 73.

225. Hori Y, Rulifson IC, Tsai BC, Heit JJ, Cahoy JD, et al. (2002) Growth inhibitors promote differentiation of insulin-producing tissue from embryonic stem cells. Proc Natl Acad Sci U S A 99: 16105-16110.

226. Kahan BW, Jacobson LM, Hullett DA, Ochoada JM, Oberley TD, et al. (2003) Pancreatic precursors and differentiated islet cell types from murine embryonic stem cells: an in vitro model to study islet differentiation. Diabetes 52: 2016-2024.

227. Blyszczuk P, Asbrand C, Rozzo A, Kania G, St-Onge L, et al. (2004) Embryonic stem cells differentiate into insulin-producing cells without selection of nestin-expressing cells. Int J Dev Biol 48: 1095-1104.

228. Leon-Quinto T, Jones J, Skoudy A, Burcin M, Soria B (2004) In vitro directed differentiation of mouse embryonic stem cells into insulinproducing cells. Diabetologia 47: 1442-1451.

229. Segev H, Fishman B, Ziskind A, Shulman M, Itskovitz-Eldor J (2004)
Differentiation of human embryonic stem cells into insulin-producing clusters. Stem Cells 22: 265-274.

230. Hori Y, Gu X, Xie X, Kim SK (2005) Differentiation of insulinproducing cells from human neural progenitor cells. PLoS Med 2: e103.

231. Miyazaki S, Yamato E, Miyazaki J (2004) Regulated expression of pdx-1 promotes in vitro differentiation of insulin-producing cells from embryonic stem cells. Diabetes 53: 1030-1037.

232. Ying QL, Wray J, Nichols J, Batlle-Morera L, Doble B, et al. (2005) The ground state of embryonic stem cell self-renewal. Nature 453: 519-523.

233. Hansson M, Tonning A, Frandsen U, Petri A, Rajagopal J, et al. (2004) Artifactual insulin release from differentiated embryonic stem cells. Diabetes 53: 2603-2609.

234. Rajagopal J, Anderson WJ, Kume S, Martinez OI, Melton DA (2003) Insulin staining of ES cell progeny from insulin uptake. Science 19: 299 363.

235. Sipione S, Eshpeter A, Lyon JG, Korbutt GS, Bleackley RC (2004) Insulin expressing cells from differentiated embryonic stem cells are not beta cells. Diabetologia 47: 499-508.

236. Kubo A, Shinozaki K, Shannon JM, Kouskoff V, Kennedy M, et al (2004) Development of definitive endoderm from embryonic stem cells in culture. Development 131: 1651-1662.

237. D“eAmour KA, Agulnick AD, Eliazer S, Kelly OG, Kroon E, et al. (2005) Efficient differentiation of human embryonic stem cells to definitive endoderm. Nat Biotechnol 23: 1534-1541.

238. D“e Amour KA, Bang AG, Eliazer S, Kelly OG, Agulnick AD, et al. (2006) Production of pancreatic hormone-expressing endocrine cells from human embryonic stem cells. Nat Biotechnol 24: 1392-1401

239. Kroon E, Martinson LA, Kadoya K, Bang AG, Kelly OG, et al. (2008) Pancreatic endoderm derived from human embryonic stem cells generates glucose-responsive insulin-secreting cells in vivo. Nat Biotechnol 26 443- 452 .

240. Mfopou JK, De Groote V, Xu X, Heimberg H, Bouwens L (2007) Sonic hedgehog and other soluble factors from differentiating embryoid bodies inhibit pancreas development. Stem Cells 25: 1156-1165.

241. Bruin JE, Erener S, Vela J, Hu X, Johnson JD, et al. (2014) Characterization of polyhormonal insulin-producing cells derived in vitro from human embryonic stem cells. Stem Cell Res 12: 194-208.

242. Zhou J, Su P, Li D, Tsang S, Duan E, et al. (2010) High-efficiency induction of neural conversion in human ESCs and human induced pluripotent stem cells with a single chemical inhibitor of transforming growth factor beta superfamily receptors. Stem Cells 28: 1741-1750.

243. Payne C, King J, Hay D (2011) The role of activin/nodal and Wnt signaling in endoderm formation. Vitam Horm 85: 207-216.

244. Jagtap S, Meganathan K, Wagh V, Natarajan K, Hescheler J, et al. (2013) All-trans retinoic acid and basic fibroblast growth factor synergistically direct pluripotent human embryonic stem cells to extraembryonic lineages. Stem Cell Res 10: 228-240.

245. Johannesson M, Ståhlberg A, Ameri J, Sand FW, Norrman K, et al (2009) FGF4 and retinoic acid direct differentiation of hESCs into PDX1expressing foregut endoderm in a time- and concentration-dependent manner. PLoS One 4: e4794.

246. Xu X, Browning VL, Odorico JS (2011) Activin, BMP and FGF pathways cooperate to promote endoderm and pancreatic lineage cell differentiation from human embryonic stem cells. Mech Dev 128: 412 427.

247. Sui L, Geens M, Sermon K, Bouwens L, Mfopou JK (2013) Role of BMP signaling in pancreatic progenitor differentiation from human embryonic stem cells. Stem Cell Rev 9: 569-577.

248. Olesnicky Killian EC, Birkholz DA, Artinger KB (2009) A role for 
chemokine signaling in neural crest cell migration and craniofacial development. Dev Biol 333: 161-172.

249. Li J, Zhu L, Qu X, Li J, Lin R, et al. (2013) Stepwise differentiation of human adipose-derived mesenchymal stem cells toward definitive endoderm and pancreatic progenitor cells by mimicking pancreatic development in vivo. Stem Cells Dev 22: 1576-1587.

250. Takizawa-Shirasawa S, Yoshie S, Yue F, Mogi A, Yokoyama T, et al. (2013) FGF7 and cell density are required for final differentiation of pancreatic amylase-positive cells from human ES cells. Cell Tissue Res 354: 751-759.

251. Li X, Romain RD, Park D, Scadden DT, Merchant JL, et al. (2014) Stress hematopoiesis is regulated by the Krüppel-like transcription factor ZBP89. Stem Cells 32: 791-801.

252. Bhonde RR, Sheshadri P, Sharma S, Kumar A (2014) Making surrogate $\beta$-cells from mesenchymal stromal cells: perspectives and future endeavors. Int J Biochem Cell Biol 46: 90-102.

253. Taylor-Weiner H, Schwarzbauer JE, Engler AJ (2013) Defined extracellular matrix components are necessary for definitive endoderm induction. Stem Cells 31: 2084-2094.

254. Ogaki S, Shiraki N, Kume K, Kume S (2013) Wnt and Notch signals guide embryonic stem cell differentiation into the intestinal lineages. Stem Cells 31: 1086-1096.

255. Frantz ED, Peixoto-Silva N, Pinheiro-Mulder A (2012) Endocrine pancreas development: effects of metabolic and intergenerational programming caused by a protein-restricted diet. Pancreas 41: 1-9.

256. Tahamtani Y, Azarnia M, Farrokhi A, Sharifi-Zarchi A, Aghdami N, et al. (2013) Treatment of human embryonic stem cells with different combinations of priming and inducing factors toward definitive endoderm. Stem Cells Dev 22: 1419-1432.

257. Chen S, Borowiak M, Fox JL, Maehr R, Osafune K, et al. (2009) A small molecule that directs differentiation of human ESCs into the pancreatic lineage. Nat Chem Biol 5: 258-265.

258. Thatava T, Nelson TJ, Edukulla R, Sakuma T, Ohmine S, et al. (2011) Indolactam V/GLP-1-mediated differentiation of human iPS cells into glucose-responsive insulin-secreting progeny. Gene Ther 18: 283-293.

259. Chen AE, Borowiak M, Sherwood RI, Kweudjeu A, Melton DA (2013) Functional evaluation of ES cell-derived endodermal populations reveals differences between Nodal and Activin A-guided differentiation. Development 140: 675-686.

260. Lahmy R, Soleimani M, Sanati MH, Behmanesh M, Kouhkan F, et al. (2014) miRNA-375 promotes beta pancreatic differentiation in human induced pluripotent stem (hiPS) cells. Mol Biol Rep 41: 2055-2066.

261. Sun K, Chang X, Yin L, Li J, Zhou T, et al. (2014) Expression and DNA methylation status of microRNA-375 in patients with type 2 diabetes mellitus. Mol Med Rep 9: 967-972.

262. Cai Q, Bonfanti P, Sambathkumar R, Vanuytsel K, Vanhove J, et al. (2014) Prospectively isolated NGN3-expressing progenitors from human embryonic stem cells give rise to pancreatic endocrine cells. Stem Cells Transl Med 3: 489-499.

263. Wei R, Yang J, Hou W, Liu G, Gao M, et al. (2013) Insulin-producing cells derived from human embryonic stem cells: comparison of definitive endoderm- and nestin-positive progenitor-based differentiation strategies. PLoS One 8: e72513.

264. Li X, Yuan J, Li W, Liu S, Hua M, et al. (2014) Direct differentiation of homogeneous human adipose stem cells into functional hepatocytes bymimicking liver embryogenesis. J Cell Physiol 229: 801-812.

265. Rezania A, Bruin JE, Xu J, Narayan K, Fox JK, et al. (2013) Enrichment of human embryonic stem cell-derived NKX6.1-expressing pancreatic progenitor cells accelerates the maturation of insulin-secreting cells in vivo. Stem Cells 31: 2432-2442.
266. Bonner-Weir S, Baxter LA, Schuppin GT, Smith FE (1993) A second pathway for regeneration of adult exocrine and endocrine pancreas. A possible recapitulation of embryonic development. Diabetes 42: 17151720 .

267. Bonner-Weir S, Taneja M, Weir GC, Tatarkiewicz K, Song KH, et al. (2000) In vitro cultivation of human islets from expanded ductal tissue. Proc Natl Acad Sci U S A 97: 7999-8004.

268. Gao R, Ustinov J, Pulkkinen MA, Lundin K, Korsgren O, et al. (2003) Characterization of endocrine progenitor cells and critical factors for their differentiation in human adult pancreatic cell culture. Diabetes 52: $2007-$ 2015.

269. Eberhardt M, Salmon P, von Mach MA, Hengstler JG, Brulport M, et al (2006) Multipotential nestin and Isl-1 positive mesenchymal stem cells isolated from human pancreatic islets. Biochem Biophys Res Commun 345: 1167-1176.

270. Zulewski H, Abraham EJ, Gerlach MJ, Daniel PB, Moritz W, et al (2001) Multipotential nestin-positive stem cells isolated from adult pancreatic islets differentiate ex vivo into pancreatic endocrine, exocrine, and hepatic phenotypes. Diabetes 50: 521-533.

271. Dor Y, Brown J, Martinez OI, Melton DA (2004) Adult pancreatic betacells are formed by self-duplication rather than stem-cell differentiation. Nature 429: 41-46.

272. Xu X, D'Hoker J, Stang G, Bonne S, De Leu N, et al. (2008) Beta cells can be generated from endogenous progenitors in injured adult mouse pancreas. Cell 132: 197-207.

273. Lee J, Sugiyama T, Liu Y, Wang J, Gu X, et al. (2013) Expansion and conversion of human pancreatic ductal cells into insulin-secreting endocrine cells. Elife 2: e00940.

274. Ianus A, Holz GG, Theise ND, Hussain MA (2003) In vivo derivation of glucose-competent pancreatic endocrine cells from bone marrow without evidence of cell fusion. J Clin Invest 111: 843-850.

275. Hess D, Li L, Martin M, Sakano S, Hill D, et al. (2003) Bone marrowderived stem cells initiate pancreatic regeneration. Nat Biotechnol 21 763-770

276. Estrada EJ, Valacchi F, Nicora E, Brieva S, Esteve C, et al. (2008) Combined treatment of intrapancreatic autologous bone marrow stem cells and hyperbaric oxygen in type 2 diabetes mellitus. Cell Transplant 17: $1295-1304$

277. Lee RH, Seo MJ, Reger RL, Spees JL, Pulin AA, et al. (2006) Multipotent stromal cells from human marrow home to and promote repair of pancreatic islets and renal glomeruli in diabetic NOD/scid mice. Proc Natl Acad Sci U S A 103: 17438-17443.

278. Antonello P (2012) Mesenchymal stem cells for the treatment of diabetes Diabetes 61: 1355-1356.

279. Aggarwal S, Pittenger MF (2005) Human mesenchymal stem cells modulate allogeneic immune cell responses. Blood 105: 1815-1822.

280. Campagnoli C, Roberts IA, Kumar S, Bennett PR, Bellantuono I, et al (2001) Identification of mesenchymal stem/progenitor cells in human first-trimester fetal blood, liver, and bone marrow. Blood 98: 2396-2402.

281. Yeung TY, Seeberger KL, Kin T, Adesida A, Jomha N, et al. (2012) Human mesenchymal stem cells protect human islets from proinflammatory cytokines. PLoS One 7: e38189.

282. Gabr MM, Zakaria MM, Refaie AF, Ismail AM, Abou-El-Mahasen MA et al. (2013) Insulin-producing cells from adult human bone marrow mesenchymal stem cells control streptozotocin-induced diabetes in nude mice. Cell Transplant 22: 133-145.

283. Dave SD, Vanikar AV, Trivedi HL (2013) Extrinsic factors promoting in vitro differentiation of insulin-secreting cells from human adipose tissuederivedmesenchymal stem cells. Appl Biochem Biotechnol 170: 962-971.

284. Nam JS, Kang HM, Kim J, Park S, Kim H, et al. (2014) Transplantation 
of insulin-secreting cells differentiated from human adipose tissuederived stem cells into type 2 diabetes mice. Biochem Biophys Res Commun 443: 775-781.

285. Thakkar UG, Trivedi HL, Vanikar AV, Dave SD (2015) Insulin-secreting adipose-derived mesenchymal stromal cells with bone marrow-derived hematopoietic stem cells from autologous and allogenic sources for type 1 diabetes mellitus. Cytotherapy 17: 940-947.

286. Vanikar AV, Dave SD, Thakkar UG, Trivedi HL (2010) Cotransplantation of adipose tissue-derived insulin-secreting mesenchymal stem cells and hematopoietic stem cells: a novel therapy for insulin-dependent diabetes mellitus. Stem Cells Int 2010: 582382.

287. Park KS, Kim YS, Kim JH, Choi B, Kim SH, et al. (2010) Trophic molecules derived from human mesenchymal stem cells enhance survival, function, and angiogenesis of isolated islets after transplantation. Transplantation 89: 509-517.

288. Rackham CL, Chagastelles PC, Nardi NB, Hauge-Evans AC, Jones PM, et al. (2011) Co-transplantation of mesenchymal stem cells maintains islet organization and morphology in mice. Diabetologia 54: 1127-1135.

289. Lu Y, Jin X, Chen Y, Li S, Yuan Y, et al. (2010) Mesenchymal stem cells protect islets from hypoxia/ reoxygenation-induced injury. Cell Biochem Funct 28: 637- 643

290. Berman DM, Willman MA, Han D, Kleiner G, Kenyon NM, et al. (2010) Mesenchymal stem cells enhance allogeneic islet engraftment in nonhuman primates. Diabetes 59: 2558-2568.

291. Kraxberger K (2015) The use of induced pluripotent stem cells in regenerative medicine. Austrian Marshall Plan Foundation, University of Applied Sciences Upper Austria Clarkson University, pp. 1-92.

292. Yamanaka S (2008) Induction of pluripotent stem cells from mouse fibroblasts by four transcription factors. Cell Prolif 41 Suppl 1: 51 56.

293. Maherali N, Hochedlinger K (2008) Induced pluripotency of mouse and human somatic cells. Cold Spring Harb Symp Quant Biol 73: 157-162.

294. Alipio Z, Liao W, Roemer EJ, Waner M, Fink LM, et al. (2010) Reversal of hyperglycemia in diabetic mouse models using induced-pluripotent stem (iPS)-derived pancreatic b like cells. Proc Natl Acad Sci U S A 107: 13426- 13431

295. Zhang D, Jiang W, Liu M, Sui X, Yin X, et al. (2009) Highly efficient differentiation of human ES cells and iPS cells into mature pancreatic insulin- producing cells. Cell Res 19: 429-438.

296. Maehr R, Chen S, Snitow M, Ludwig T, Yagasaki L, et al. (2009) Generation of pluripotent stem cells from patients with type 1 diabetes. Proc Natl Acad Sci U S A 106: 15768-15773.

297. Lister R, Pelizzola M, Kida YS, Hawkins RD, Nery J, et al. (2011) Hotspots of aberrant epigenomic reprogramming in human induced pluripotent stem cells. Nature 471: 68-73.

298. Suzuki A, Nakauchi H, Taniguchi H (2003) Glucagon-like peptide 1 (137) converts intestinal epithelial cells into insulin-producing cells. Proc Natl Acad Sci U S A 100: 5034-5039.

299. Yoshida S, Kajimoto Y, Yasuda T, Watada H, Fujitani Y, et al. (2002) PDX-1 induces differentiation of intestinal epithelioid IEC-6 into insulinproducing cells. Diabetes 51: 2505-2513.

300. Okumura K, Nakamura K, Hisatomi Y, Nagano K, Tanaka Y, et al. (2003) Salivary gland progenitor cells induced by duct ligation differentiate into hepatic and pancreatic lineages. Hepatology 38: 104 113.

301. Timper K, Seboek D, Eberhardt M, Linscheid P, Christ-Crain M, et al (2006) Human adipose tissue-derived mesenchymal stem cells differentiate into insulin, somatostatin, and glucagon expressing cells. Biochem Biophys Res Commun 341: 1135-1140.

302. Ber I, Shternhall K, Perl S, Ohanuna Z, Goldberg I, et al. (2003)
Functional, persistent, and extended liver to pancreas transdifferentiation J Biol Chem278: 31950-31957.

303. Kim S, Shin JS, Kim HJ, Fisher RC, Lee MJ, et al. (2007) Streptozotocininduced diabetes can be reversed by hepatic oval cell activation through hepatic transdifferentiation and pancreatic islet regeneration. Lab Invest 87: 702-712.

304. Sapir T, Shternhall K, Meivar-Levy I, Blumenfeld T, Cohen H, et al (2005) Cell-replacement therapy for diabetes: generating functional insulin- producing tissue from adult human liver cells. Proc Natl Acad Sci U S A 102: 7964-7969.

305. Yang L, Li S, Hatch H, Ahrens K, Cornelius JG, et al. (2002) In vitro trans- differentiation of adult hepatic stem cells into pancreatic endocrine hormone- producing cells. Proc Natl Acad Sci U S A 99: 8078-8083.

306. Zalzman M, Gupta S, Giri RK, Berkovich I, Sappal BS, et al. (2003) Reversal of hyperglycemia in mice by using human expandable insulin producing cells differentiated from fetal liver progenitor cells. Proc Natl Acad Sci U S A 100: 7253-7258.

307. Graf T, Enver T (2009) Forcing cells to change lineages. Nature 462: 587 594.

308. Vierbuchen T, Wernig M (2011) Direct lineage conversions: unnatural but useful? Nat Biotechnol 29: 892-907.

309. Yang XF, Ren LW, Li FR (2015) Direct reprogramming: a new strategy for the treatment of diabetes. J Endocrinol Diabetes Obes 3: 1-8.

310. Swales N, Martens GA, Bonné S, Heremans Y, Borup R, et al. (2012) Plasticity of adult human pancreatic duct cells by neurogenin3-mediated reprogramming. PLoS One 7: e37055.

311. Yang YP, Thorel F, Boyer DF, Herrera PL, Wright CV (2011) Contextspecific $\alpha$ - to- $\beta$-cell reprogramming by forced Pdx1 expression. Genes Dev 25: 1680-1685.

312. Hickey RD, Galivo F, Schug J, Brehm MA, Haft A, et al. (2013) Generation of islet-like cells from mouse gall bladder by direct ex vivo reprogramming. Stem Cell Res 11: 503-515.

313. Motoyama H, Ogawa S, Kubo A, Miwa S, Nakayama J, et al. (2009) In vitro reprogramming of adult hepatocytes into insulin-producing cells without viral vectors. Biochem Biophys Res Commun 385: 123-128

314. Cim A, Sawyer GJ, Zhang X, Su H, Collins L, et al. (2012) In vivo studies on non-viral transdifferentiation of liver cells towards pancreatic $\beta$ cells. J Endocrinol 214: 277-288

315. Aviv V, Meivar-Levy I, Rachmut IH, Rubinek T, Mor E, et al. (2009) Exendin-4 promotes liver cell proliferation and enhances the PDX-1induced liver to pancreas transdifferentiation process. J Biol Chem 284 33509-33520.

316. Thorel F, Népote V, Avril I, Kohno K, Desgraz R, et al. (2010) Conversion of adult pancreatic alpha-cells to beta-cells after extreme beta-cell loss. Nature 464: 1149-1154.

317. Bramswig NC, Everett LJ, Schug J, Dorrell C, Liu C, et al. (2013) Epigenomic plasticity enables human pancreatic $\alpha$ to $\beta$ cell reprogramming. J Clin Invest 123: 1275-1284.

318. Chung CH, Hao E, Piran R, Keinan E, Levine F (2010) Pancreatic $\beta$-cell neogenesis by direct conversion from mature $\alpha$-cells. Stem Cells 28: $1630-1638$.

319. Zhou Q, Brown J, Kanarek A, Rajagopal J, Melton DA (2008) In vivo reprogramming of adult pancreatic exocrine cells to beta-cells. Nature 455: $627-632$.

320. Akinci E, Banga A, Greder LV, Dutton JR, Slack JM (2012) Reprogramming of pancreatic exocrine cells towards a beta $(\beta)$ cell character using Pdx1, Ngn3 and MafA. Biochem J 442: 539-550.

321. Furuya F, Shimura H, Asami K, Ichijo S, Takahashi K, et al. (2013) Ligand- bound thyroid hormone receptor contributes to reprogramming of 
Citation: Ahmed OM, Sayed HM. Stem Cell Therapies in Regenerative Medicine and Diabetes Mellitus: Advances, Constraints and Future Prospects. $J$ Transplant Stem Cel Biol. 2016;3(1): 22.

ISSN: $2374-9326$

pancreatic acinar cells into insulin-producing cells. J Biol Chem 288: $16155-16166$.

322. Nagaya M, Katsuta H, Kaneto H, Bonner-Weir S, Weir GC (2009) Adult mouse intrahepatic biliary epithelial cells induced in vitro to become insulin-producing cells. J Endocrinol 201: 37-47.

323. Coad RA, Dutton JR, Tosh D, Slack JM (2009) Inhibition of Hes1 activity in gall bladder epithelial cells promotes insulin expression and glucose responsiveness. Biochem Cell Biol 87: 975-987.

324. Sheik Abdulazeez S (2015) Diabetes treatment: a rapid review of the current and future scope of stem cell research. Saudi Pharm J 23: 333340 .

325. Hotta Y (2008) Ethical issues of the research on human embryonic stem cells. J Int Bioethique 19: 77-85, 124-125.
326. Moller M (2009) Human embryonic stem cell research and the discarded embryo argument. Theor Med Bioeth 30: 131-145.

327. Stanford Encyclopedia of Philosophy (2013) Ethics of stem cell research.

328. Dajani R (2014) Jordan's stem-cell law can guide the Middle East. Nature 510: 189.

329. Ismail A (2015) Stem cell research and ethics: an update. Oman Med J 30: $1-2$

330. Harris J, Bortolotti L, Irving L (2005) An ethical framework for stem cell research in the European Union. Health Care Anal 13: 157-162.

331. Daar AS, Bhatt A, Court E, Singer PA (2004) Stem cell research and transplantation: science leading ethics. Transplant Proc 36: 2504-2506. 